\title{
Environmental significance of microbialites in reef environments during the last deglaciation
}

\author{
G. Camoin ${ }^{a},{ }^{\star}$, G. Cabioch ${ }^{b}$, A. Eisenhauer ${ }^{c}$, J.-C. Braga ${ }^{d}$, B. Hamelin ${ }^{a}$ and G. Lericolais ${ }^{e}$ \\ ${ }^{a}$ CEREGE, CNRS. UMR 6635, B.P. 80, F-13545 Aix-en-Provence cedex 4 France \\ b IRD, UR 055, Centre de Nouméa, BP A5, 98848 Nouméa cedex, New Caledonia \\ ${ }^{\mathrm{C}}$ GEOMAR, Wischhofstrasse 1-3, D-24148 Kiel, Germany \\ dUniversidad de Granada,Estratigrafia y paleontologia, Campus Fuentenueva, E-18002, Granada, Spain \\ e IFREMER, DRO/GM- BP 70, F-29280 PLOUZANE cedex, France
}

*: Corresponding author : G. Camoin, email address : camoin@cerege.fr

\begin{abstract}
:
In situ microbialites occurring in reef rocks dredged between 80 and $130 \mathrm{~m}$ water depth on the modern fore-reef slopes of Tahiti and the Marquesas islands yield ages ranging from 17,100 \pm 2900 to $4410 \pm$ 2250 years BP, suggesting that they played a prominent role during the last deglacial sea level rise.

Microbialites developed in both shallow and deep water depositional environments where they characterize various zones of the reef tracts (reef crests, upper reef slopes, deep fore-reef slopes), reflecting contrasting scenarios of microbialite development involving «reefal microbialites» in shallowwater settings and «slope microbialites» that formed in environments deeper than $10-20 \mathrm{~m}$ and extending down to more than $100 \mathrm{~m}$.
\end{abstract}

Reefal microbialites correspond to a late stage of encrustation of the dead parts of coral colonies, or more commonly, of related encrusting organisms (red algae and foraminifers), thus forming surface crusts. Slope microbialites generally form the ultimate stage of a biological succession indicating a deepening sequence, whereby shallow water corals and associated encrusting organisms are replaced by deeper water assemblages of red algae and foraminifers before microbialite growth. The precipitation of phosphatic-iron-manganese crusts and the deposition of planktonic micritic limestones on the microbialites characterize a deepening-upward sequence.

The widespread development of microbialites in reef sequences from the Last Deglaciation characterizes a period of environmental degradation consequential on the rapid sea-level rise and abrupt climatic changes of that time. The reported biological succession reflects changes in water quality, and especially an increase in nutrients. In shallow-water settings, increased alkalinity and nutrient availability in interstitial waters were related to surface fluxes and terrestrial groundwater seepage while slope environments were exposed to continuous upwelling of nutrient-rich deeper waters during the last deglacial sea level rise.

The age differences between corals and overlying slope microbialites range from 1600 to 8400 years, based on high-precision U-series age measurements of both corals and microbialites, and indicates that a significant time (several thousand years) elapsed between the development of the coralgal frameworks and the growth of slope microbialite crusts. Microbialites cannot be considered as part of the drowning event some 14,000 years ago that resulted in the demise of reef frameworks in the 90$110 \mathrm{~m}$ present depth range, but are substantially younger.

Keywords: Coral reefs; Microbialites; Last deglaciation; Holocene; French polynesia; Nutrients; Sea level changes 


\section{Introduction}

Coral reefs are sensitive recorders of past sea level and environmental changes. Their accurate dating by mass spectrometry is of prime importance to the understanding of the mechanisms driving glacialinterglacial cycles during Quaternary times. Due to their growth within a narrow depth window, coral reefs represent excellent sea level indicators. High-resolution records of past global changes (especially temperature and salinity changes) are stored in the geochemical and physical parameters of coral skeletons and reef sequences and can be used to examine ocean/atmosphere variability. Changes in other environmental parameters such as light conditions, water energy and nutrient levels are usually reflected in variations in the composition of reef communities, as reef-dwelling organisms are sensitive to subtle ecological changes affecting their environment.

The Last Deglaciation (23-6 ka BP) is generally seen as a potential recent analog for the environmental changes that our Planet may face in the near future as a consequence of ocean thermal expansion and the melting of polar ice-sheets related to the greenhouse effect. The study of coral reef records of the last deglacial events are therefore of prime importance in constraining the timing and amplitude of rapid sea level changes and other related abrupt environmental changes and evaluating their impact on coral reef development.

Because the amplitude of sea level changes during the Last Deglaciation was at least $120 \mathrm{~m}$ (Fairbanks, 1989), the relevant reef and sediment archives are mostly stored on modern fore-reef slopes, where last deglacial reef sequences have been investigated by drilling, dredging and submersible sampling. So far, the only coral reef record that encompasses the whole of the Last Deglaciation is from Barbados where it was suggested that this period was characterized by two brief intervals of accelerated melting (MWP-1A and MWP-1B events centered on 14,000 and 11,300 cal. yr BP respectively) superimposed on a smooth and continuous rise of sea level with no reversals (Fairbanks, 1989; Bard et al., 1990). However, doubts concerning the general pattern of sea-level rise during this time window remain. Data obtained by dredging (e.g. Rougerie et al., 1992) and submersible sampling (e.g. James and Ginsburg, 1979; Land and Moore, 1980 ; Macintyre et al., 1991; Brachert and Dullo, 1991, 1994; Grammer et al., 1993; Brachert, 1994; Dullo et al., 1998; Webster et al., 2004a,b) are typically fragmentary but have brought to light valuable information regarding the interpretation of morphological features, both accretionary (e.g. terraces, relict reefs) and erosional (e.g. cliffs, notches), in relation to sea level changes. In particular, the levels of relict reefs that have been reported in various regions at present water depths of 90-100 and 55-65 m (Caribbean: McIntyre et al., 1991; Grammer et al., 1993; Marquesas islands: Rougerie et al., 1992; Mayotte: Dullo et al., 1998; Camoin et al., 2004) are thought to have been related to reef drowning events during meltwater pulses. However, the abrupt and significant environmental changes that accompanied the deglacial sea level rise have barely been investigated so that the accurate reconstruction of the event is obscured. In particular, there are few studies that tackle the environmental changes recorded by changes in reef communities.

Among biological indicators of environmental change, the abundance of microbial fabrics, referred as «microbialites» (Burne and Moore, 1987), first described in the post-glacial reef sequence of Tahiti (Montaggioni and Camoin, 1993), has been reported in Late Pleistocene to Holocene reef frameworks from a number of areas (Camoin and Montaggioni, 1994; Webb, 1996; Camoin et al., 1997; Cabioch et al., 1998; Camoin et al., 1999; Camoin et al., 2004). However, more detailed studies of the contrasting environmental settings and varied time windows in which they occur are still required in order to evaluate their environmental significance and relative importance in Quaternary reef tracts. Lithified micritic crusts, now generally regarded as microbialites, have been described on the walls of many deep forereefs (Moore et al., 1976; James and Ginsburg, 1979; Land and Moore, 1980; Brachert and Dullo, 1991, 1994; Brachert, 1994; Dullo et al., 1998), suggesting that they may have developed during the early part of the Last Deglaciation, but studies generally omit any interpretation of their environmental significance.

Here we present data on reef sequences from the last deglacial interval recently acquired from the fore-reef slopes from two Polynesian sites, Tahiti and the Marquesas islands. These complement results relating to the last 13,000 years obtained from cores drilled on the Papeete barrier reef (Camoin et al., 1999). The objectives of this paper are: 1 ) to document the distribution of microbialites in time and space, and to analyze their sedimentological role in these reef sequences; and 2) to reconstruct paleoenvironmental settings during the last deglacial time window.

Biosedimentological, geochemical and biochemical data concerning the nature of the microbialites will be the subject of a separate paper (Camoin et al., work in progress). 


\section{Geographical and environmental settings}

The two sites studied are in French Polynesia (Central Pacific Ocean; Fig. 1).

Tahiti is a volcanic island (2241 m maximum altitude) situated at $17^{\circ} 50 \mathrm{~S}$ and $149^{\circ} 20 \mathrm{~W}$ in the Society Archipelago. It consists of twin shield volcanoes that were active $1.367 \pm 0.016 \mathrm{Ma}$ to $0.187 \pm 0.003 \mathrm{Ma}$ ago (Le Roy, 1994). Subsidence rates deduced from the ages of subaerial lavas beneath the Pleistocene reef sequence range from $0.15 \mathrm{~mm} \mathrm{yr}^{-1}$ (Le Roy, 1994) to $0.25 \mathrm{~mm} \mathrm{yr}^{-1}$ (Bard et al., 1996).

Tahiti lies in the well-ventilated South Pacific gyre. The climate is typically tropical, with two distinct seasons: a warm rainy season from November to April (austral summer), with maximum sea surface temperatures from 28 to $29^{\circ} \mathrm{C}$, and a cool dry season from May to October (austral winter), with lower sea-water temperatures of 24 to $25^{\circ} \mathrm{C}$ (see Delesalle et al., 1985 for further information). Although the annual rainfall averages $1,500 \mathrm{~mm}$ on Papeete, there are marked variations in rain intensity throughout the year: with minimum monthly values in winter less than $50 \mathrm{~mm}$, and maximum monthly values in January and February up to $400 \mathrm{~mm}$. The prevailing south-east and north-east trade winds determine the hydrological regime and generate swells more than $2 \mathrm{~m}$ amplitude along the long axis of the island. Tides are semi-diurnal and amplitude averages $0.5 \mathrm{~m}$; reef flats emerge at spring tides and waves commonly break on the central areas of reef flats at high tide. Tahiti is surrounded by discontinuous fringing reefs that grade locally into an equally discontinuous chain of barrier reefs, locally enclosing a narrow lagoon.

The Marquesas archipelago comprises twelve volcanic islands that stretch for 350 to $400 \mathrm{kms}$, between $8^{\circ}$ and $11^{\circ} \mathrm{S}$ and between $141^{\circ}$ and $138^{\circ} \mathrm{W}$ (Fig. 1). The islands are aligned along a $150^{\circ}$ trend that differs from the $115^{\circ}$ to $120^{\circ}$ general trend that characterizes Pacific plate motion; the underlying oceanic crust ranges from 1 to $5 \mathrm{Ma}$ old (Clouard, 2000). Subsidence seems to have been negligible as the Last Interglacial reef terrace (i.e. $125 \mathrm{ka}$ ) lies only 2 - $5 \mathrm{~m}$ above present sea level (Guille et al., 2002) and probably originally developed $6 \mathrm{~m}$ above present sea level during substage 5e (Broecker et al., 1968; Bloom et al., 1974; Kaufman, 1985).

The Marquesas islands lie close to the Equator, within the South Equatorial westward drift, in an area highly influenced by ENSO events and characterized by an abundance of phytoplankton (Sournia, 1976; Signorini et al., 1999). Modern reefs are poorly developed and are restricted to few bays where they typically form banks or narrow fringing reefs at a depth of 5-6 m or, more rarely, around 20-25 m (Chevalier, 1978). As a consequence, there are less than 30 species of corals. The two most abundant genera are Porites and Pocillopora; Acropora is absent (Chevalier, 1978).

\section{Material and methods}

The fore-reef slopes studied were investigated during 1997 (cruises «Musorstom» and «Paleomarq»; Rougerie and Cabioch, 1997; Richer de Forges et al., 1999) and 2002 (cruise «ReMarq»; Cabioch et al., 2003) in the Marquesas islands and in 2002 in Tahiti (cruise «SISMITA»; Camoin et al., 2003) aboard the $\mathrm{R} / \mathrm{V}$ «Alis» owned by the French National «Institut de Recherche pour le Développement».

During the «ReMarq» and «SISMITA» cruises multibeam bathymetric data were acquired using a SIMRAD EM 1002 at depths ranging from 50 to $250 \mathrm{~m}$. Bathymetric data were postprocessed using the software CARAIB. Bathymetric data processed at sea allowed us to select suitable targets for dredging. High resolution seismic data were acquired around Tahiti using Sparker and Delph systems to image the structure of the reef sequences and the underlying basement.

The most significant imaged and mapped morphological features were "ground-truthed" by dredging (38 dredges around Tahiti; 22 in 1997 and 76 in 2002 in the Marquesas) carried out on reef terraces, drowned reefs and slopes. Around Tahiti (offshore Papeete-Faaa, Tiarei and Maraa) depths ranged from 50 to $500 \mathrm{~m}$ (Fig. 1). In the Marquesas islands, dredge depths ranged from 90 to $130 \mathrm{~m}$ (DR 1246) around Fatu Hiva and 86 and 120 m (DR 1182 and DR 1183) around Nuku Hiva (Fig. 1). In both studied areas, the dredges yielded reef material including coral colonies and fragments, coralline algal encrustations and microbialites. Datable material has been obtained at all depths within the bathymetric range involved during the development of the post-glacial reef sequence (i.e. down to 120-140 m below the present sea surface). A combination of criteria was used to distinguish in-situ carbonate material and reworked samples: (1) whether the sample was broken off or collected loose; (2) the convergence between the presence of dark manganese-iron crusts on the exposed outer surface and the occurrence of macroscopic and microscopic sediment geopetals in cavities indicating a similar orientation; (3) the lack of severe surface abrasion and rounding of coral colonies; 4) the orientation of corallites and the tips of branching acroporids and pocilloporids; and 5) the encrustation of coral branches by coralline algal crusts. 
Corals and microbialites selected for radiometric dating were examined petrographically and by $\mathrm{X}$ ray diffraction to check skeletal aragonite/calcite ratios in order to exclude diagenetically altered material. However, the corals from both sites have been submerged in seawater since the time of their growth and have been protected from major recrystallization/dissolution processes. An accurate chronology has been achieved through radiometric dating of these corals and microbialites by U-Th thermal ionisation mass spectrometry (TIMS) at GEOMAR, Kiel (see Tabl. 1). Most of the U-Th radiometric ages obtained are close to the value of modern seawater (149.7 $\pm 1.5 \%$; see Edwards et al., 1987; Gallup et al., 1994; Bard et al., 1996) and are therefore considered as 'strictly reliable' (see Stirling et al., 1998). Although the ${ }^{230} \mathrm{Th} /{ }^{238} \mathrm{U}$ ratios for most samples could be determined with great precision some ages obtained from microbialites are burdened by relatively high statistical errors because of the high contribution of detrital ${ }^{230} \mathrm{Th}$.

In order to estimate depositional paleodepth, the biological communities, including corals, green and red algae and foraminifers, have been classified according to their depth range, relative light levels, and water energy requirements by analogy with the general distribution of their modern Indo-Pacific counterparts and, more specifically, those of the modern reefs of the islands studied.

The carbonate rocks recovered, especially the microbialites, were examined using standard petrographic microscopes, SEM, X-ray diffraction and specific staining techniques. Over 150 thin sections were prepared from the dredged samples some, gently etched, were examined with a Hitachi S570 scanning electron microscope. Microsamples were taken from microbialites and corals using a miniature lathe fitted with a $0.6 \mathrm{~mm}$ diameter dental drill; the drilling routine was observed under a binocular microscope.

Stable isotope analyses (carbon and oxygen) on coral and microbialite samples were carried out at the University of Erlangen on a FINNIGAN MAT 252 connected to an online carbonate preparation line (Carbo-Kiel - single sample acid bath) and on a FINNIGAN MAT 251 mass-spectrometer coupled with a standard «Bremen Carbonate Device». Reproducibility is $0.04 \%$ PDB for $\delta^{18} \mathrm{O}$ and $0.03 \%$ PDB for $\delta^{13} \mathrm{C}$.

\section{Results}

\subsection{Morphology of the fore-reef slopes and chronological frame}

Previous data concerning the fore-reef slopes of both sites were limited to scarce bathymetric and morphological observations. The occurrence of two prominent terraces off Papeete (Tahiti), at $50 \mathrm{~m}$ and $90-$ $100 \mathrm{~m}$ respectively, was demonstrated by Salvat et al. (1985) during a survey by the submersible «Cyana» and relevant bathymetric data were obtained from the Port Autonome Papeete, the Service Hydrographique de la Marine and IFREMER.

In Marquesas islands, cruises conducted by the Service Hydrographique de la Marine (Brousse et al., 1978) and the CEA (Cruises «HYDROPOL», 1986-1989, R/V BOCB «Marara») provided information on the occurrence of a reef platform surrounding the islands at around $90 \mathrm{~m}$ water depth (Rougerie et al., 1992).

A separate paper detailing the structure and morphology of the fore-reef slopes will be presented elsewhere.

\subsubsection{Tahiti}

The overall morphology of the reef foreslopes as obtained from bathymetric data and seismic profiling shows consistent features around Tahiti, although the relative importance of features differs from site to site, suggesting a complex history of reef growth and drowning.

Two major terraces have been mapped and imaged, at 50-60 m and 90-100 m respectively; a third narrower terrace occurs locally at 75-80 m water depth.

The extensive terrace at 50-60 m water depth is inclined gently seawards down to $90 \mathrm{~m}$. On the eastern side of the island, it is bounded upslope by a series of pinnacles up to $150 \mathrm{~m}$ in diameter that rise from the sea-floor to about $20 \mathrm{~m}$ water depth. The reef sequence deposited on this terrace forms a sedimentary wedge that pinches out at a depth of $90 \mathrm{~m}$ in the Tiarei area.

The prominent terrace at 90 to $100 \mathrm{~m}$ depth bears abundant build-ups that are interpreted as relict reefs based on the study of dredged samples. In the Tiarei area, these range in height from $30 \mathrm{~m}$ (base at $100 \mathrm{~m}$, top at $70 \mathrm{~m}$ below sea level), up to $45 \mathrm{~m}$ (base at $90 \mathrm{~m}$, top at $45 \mathrm{~m}$ below sea level). There is a clear topographic break at $90-100 \mathrm{~m}$ water depth where the slope steepens sharply.

The ages obtained from corals dredged in the 100-120 $\mathrm{m}$ depth interval range from $13,123 \pm 64$ to $15,052 \pm 91$ yrs BP (Tab. 1) and are in good agreement with those obtained from the base of the cores from 
holes drilled on the Papeete barrier reef $(13,750$ and 13,850 yrs BP at 85 and $88 \mathrm{~m}$ below the reef surface respectively; Bard et al., 1996; Montaggioni et al., 1997; Camoin et al., 1999).

The transitional zone between the 90-100 m terrace and the talus that characterizes the 200-250 m depth interval may be either an almost vertical wall $\left(75^{\circ}\right.$ to $\left.90^{\circ}\right)$ or a steep slope, although a significant break in slope has also been observed at 120-130 m water depth. The slope generally consists of a series of laterally discontinuous ledges and has the appearance of being highly stratified down to $200 \mathrm{~m}$ water depth. Buildups, up to $45 \mathrm{~m}$ high (base at $135 \mathrm{~m}$, top at $90 \mathrm{~m}$ below sea level), occur locally on the slope and are interpreted as relict reef ridges. Most of the corals recovered within this depth range provide very young ages $(<1,000 \mathrm{yrs} \mathrm{BP})$, indicating that they were more recently transported from a shallower landward phase of reef growth.

\subsubsection{Marquesas}

The overall morphology of the Marquesas islands foreslopes is similar to that of the Tahiti fore-reef slopes. The first significant break in slope occurs at $45 \mathrm{~m}$ water depth (Cabioch et al., 2003). However, three other distinctive terraces have been recorded, at around 60, 80 and $90 \mathrm{~m}$ water depth, separated by gently inclined slopes. Below the $90 \mathrm{~m}$ deep terrace, the slope steepens to form an almost vertical wall on which significant breaks in slope occur at 118 and $126 \mathrm{~m}$ water depth.

Dredges at depths ranging from 80 to $130 \mathrm{~m}$ around Fatu Hiva (DR 1246), Hiva Oa (DR 8b), Nuku Hiva (DR 1182 and DR 1183) and Eiao (DR 9) (Fig. 1) recovered fossil corals (mainly Porites spp. and to a less extent Pocillopora) that yielded ages ranging from 12,452 \pm 65 to 16,194 \pm 81 yrs BP (Tab.1). Ages ranging from 3,000 to 15,000 yrs BP (Paterne et al., 2004) and older than 20,000 yrs BP (Cabioch et al., 2000; Paterne et al., 2004) were previously reported. The present study focused on the $90 \mathrm{~m}$ deep terrace previously interpreted as a relict barrier reef drowned during the last deglacial sea level rise (Rougerie et al., 1992). The reefal origin of this feature was demonstrated using corals dredged from the surface (Brousse et al., 1978, Rougerie et al., 1992, Cabioch et al., 2000, 2003) that yielded ages around 15,000 yrs BP (Paterne et al., 2004).

\subsection{Sedimentary facies and depositional environments}

In both sites the dredged samples included corals, algal-foraminiferal crusts, microbialites, phosphatic-ironmanganese crusts, reworked skeletal limestones and planktonic micritic limestones (Figs 2, 3 \& 4). The occurrence of multiple generations of borings on some surfaces indicates that these represent submarine hardgrounds characterized by lithification and bioerosion (Fig. 2).

The characteristics and distribution of the microbialites are described below.

The distributional patterns of reef-building organisms, especially corals and coralline algae, but also associated organisms depends essentially on light intensity and wave-energy conditions (see e.g. Adey et al., 1982; Done, 1982; Faure, 1982; Adey, 1986; Veron, 1986; Bouchon, 1996), although significant variations may occur in response to local environmental factors such as nutrient and freshwater inputs, turbidity etc.

\subsubsection{Corals}

Samples dredged on the Tahiti slopes are dominated by branching corals, including both Acropora and Pocillopora, whereas those from the Marquesas islands are characterized by abundant massive Porites associated with fewer branching Pocillopora. These assemblages reflect environments in water depths less than 20 m (compare Faure, 1982; Veron, 1986; Bouchon, 1996).

\subsubsection{Algal-foraminiferal crusts}

Corals are usually heavily coated with red algae and encrusting benthic foraminifers that generally form three successive assemblages :

a) Assemblage $I$ is dominated by thick algal-foraminiferal crusts of Hydrolithon onkodes, H. munitum, Neogoniolithon conicum and Peyssonnelliaceae associated with encrusting foraminifers (Homotrema rubrum, Carpenteria cf. monticularis and Acervulina inhaerens) and sessile vermetid gastropods (Serpulorbis annulatus and Dendropoma maximus). Sediments associated with these crusts consist of skeletal sands including benthic foraminifers (Amphistegina, rotalids), bryozoans, fragments of red algae and Halimeda, and volcanic grains. Pores are generally lined by thin isopachous fringes of bladed high-Mg calcite. Large cavities are plastered with varied microbial features. 
In recent reef environments in the Indo-Pacific region assemblage I, dominated by members of the subfamily Mastophoroideae (Hydrolithon onkodes), characterizes reef crests and uppermost reef slopes exposed to strong wave action in water depths less than $10 \mathrm{~m}$ (eg. Hawaii, Adey et al., 1982; Great Barrier Reef, Adey, 1986; Borowitza and Larkum, 1986; Tahiti, Montaggioni et al., 1997, Camoin et al., 1999, Cabioch et al., 1999a, b; Ryukyus: Iryu et al., 1995; Papua New Guinea, Matsuda et al., 1994, Webster et al., 2004a), or even less than $3 \mathrm{~m}$ below spring low tides where vermetid gastropods are associated (Richard, 1982; Laborel, 1986). The assemblage formed by robust branching corals, Hydrolithon and vermetid gastropods is regarded as the bathymetric counterpart of the Acropora palmata/Lithophyllum congestum/Hydrolithon pachydermum assemblage described from the Caribbean (Lighty et al., 1982; Cabioch et al., 1999b).

b) Assemblage II is composed of Lithophyllum prototypum (=Lithophyllum tessellatum), L. gr. pustulatum, Lithothamnion prolifer, Mesophyllum sp., Lithothamnion sp. and Lithoporella sp. associated with Homotrema rubrum and Acervulina inhaerens.

Assemblage II, dominated by members of the subfamily Lithophylloideae, is indicative of environments characterized by a low to moderate energy and depths greater than $10 \mathrm{~m}$, and generally in the $10-20 \mathrm{~m}$ range (Cabioch et al., 1999b; Ringeltaube and Harvey, 2000). Braga and Aguirre (2004) noted that similar assemblages dominated by Lithophylloid algae have either a widespread geographical distribution or a wide depth range. However, here the absence of shallow-water mastophoroid species suggests that this assemblage grew in deeper waters not suitable for forms such as Hydrolithon onkodes and Neogoniolithon that typify very shallow-water environments.

c) Assemblage III comprises Mesophyllum, Lithothamnion, Lithophyllum gr. pustulatum and Lithoporella. Sediments interlayered with the crusts formed by assemblages II and III consist of fine grained skeletal sands including benthic and planktonic foraminifers, spicules of alcyonarians and phosphatic grains.

Assemblage III mostly comprises species of the subfamily Melobesioideae and characterizes fore-reef environments deeper than $20 \mathrm{~m}$, extending to more than $100 \mathrm{~m}$ depending on the prevailing local conditions (Adey, 1979; Adey, 1986). Mesophyllum and Lithothamnion are the main components of rhodoliths and crusts growing on the outer platform off Fraser Island (southern Queensland) and the Great Barrier Reef, between 60 and 110 m (Lund, 1994; Lund et al., 2000; Marshall et al., 1998; Davies et al., 2004). Similar assemblages have been reported between 60 and $80 \mathrm{~m}$ in New Caledonia (Rio et al., 1991), and between 70 and $90 \mathrm{~m}$ in the Caribbean (Minnery et al., 1985). A similar coralline-foraminiferal crust has been interpreted as deposited in fore-reef slope environments in the 60-90 m depth range on drowned carbonate platforms from the Huon Gulf, Papua New Guinea (Webster et al., 2004a).

\subsubsection{Phosphatic-Iron-Manganese crusts}

The upper surfaces of the microbialites are thickly coated with multiple generations of stacked digitate and laminated accretions of phosphate (brushite), iron (goethite) and manganese, $50 \mu \mathrm{m}$ average thickness, that also occur in primary cavities of the underlying corals and rim lithophagid borings in the microbialites. Additional studies will be required to determine any microbial involvement in their formation.

Fine-grained sediments containing planktonic micro-organisms are usually interlayered with the phosphatic, iron and manganese crusts. The crusts represent local unconformities characterizing periods with no carbonate precipitation and slow to nil sedimentation. Phosphate deposits are commonly associated with marine condensed sections and indicate periods of slow deposition during periods of maximum rates of sealevel rise and sea-level highstands (Föllmi, 1996).

Commonly Phosphatic-Iron-Manganese crusts have been mechanically reworked several times. The production of clasts included in the crusts is seemingly related to intense boring activity and to erosion and redeposition, probably as a result of bottom-water activity. Similar phosphatic-iron-manganese crusts have commonly been reported on fore-reef slopes where they have mostly been interpreted as formed at depths greater than $100 \mathrm{~m}$ (Belize; James and Ginsburg, 1979). Similar conclusions were reached regarding the formation of phosphatic-manganese crusts capping present Pacific guyots that probably developed after drowning of the Cretaceous carbonate platforms (Camoin et al., 1998).

\subsubsection{Reworked skeletal limestones}

Redeposited coarse skeletal sands are cemented by bladed high-Mg calcite and consist of reworked fragments of red algae (Mesophyllum, Amphiroa, Lithophyllum gr. pustulatum, Lithoporella sp. and Peyssonneliaceans) and foraminifer crusts, abundant Halimeda plates, benthic foraminifers (Amphistegina), and fragments of corals, echinoids and gastropods. These limestones may overlie the eroded surfaces of microbial crusts and may contain reworked clasts of microbial laminates. 


\subsubsection{Planktonic micritic limestones}

Planktonic micritic limestones clearly represent the last sediment deposited as they cover the phosphatic and iron-oxide crusts and fill multiple borings in these and in microbialites (Figs $3 \& 4$ ). They are themselves usually stained by phosphate and iron and are characterized by the abundance of planktonic foraminifers, spicules of alcyonarians, and phosphatic grains. Reworked grains include small benthic foraminifers (Amphistegina) and fragments of echinoids, red algae and Halimeda that are typically coated by phosphatic films. These characteristics suggest a deep water environment with no precise indication of depositional depth but probably deeper than $100 \mathrm{~m}$. The interlayering of phosphate (brushite) and iron oxide (goethite) films in these sediments indicates the persistence of the mobilization of phosphate, iron and manganese during the deposition of the planktonic limestones.

\subsection{Microbialites}

\subsubsection{Distribution in space and time}

Microbialites occur in samples dredged from all depths on the studied slopes, between 80 and 500 $\mathrm{m}$ water depth off Tahiti and between 90 and $130 \mathrm{~m}$ off the Marquesas. However, in both areas, they were collected in situ only in the upper parts of their depth ranges, mostly between 80 and $150 \mathrm{~m}$, close to the prominent terrace at $90 \mathrm{~m}$ water depth and on the upper part of the steep slope below this terrace. Dredges at depths greater than $200 \mathrm{~m}$ collected only loose material. Ages obtained on microbialite crusts and corals are reported in Table 1. yrs BP.

Microbialites in situ on the $90 \mathrm{~m}$ terrace yielded ages ranging from $4,410 \pm 2,250$ to $12,000 \pm 2,700$

The ages of microbialites in the 100-120 m depth range are distributed in two groups: 1) from 8,300 $\pm 1,700$ to $9,800 \pm 1,600 \mathrm{yrs} \mathrm{BP}$; and 2) from $16,100 \pm 2,200$ to $17,100 \pm 2,900 \mathrm{yrs}$ BP. Corals from the same depth interval yielded ages ranging from $13,123 \pm 64$ to $15,052 \pm 91$ yrs BP, implying a disparity in ages between the microbialites and the corals of from 1,600 to 8,400 years, taking into account the error range of the microbialite ages. Dates obtained from the same sample display an age difference of a few thousand years between the coral and the overlying microbialite crust (e.g. 13,123 \pm 64 yrs against 8,600 \pm 2,900 yrs BP respectively), indicating that a significant time elapsed between the growth of the coral and the development of the microbialite crust. An age of 7,380 $\pm 148 \mathrm{yrs}$ BP was obtained from a mollusc shell encrusting the microbialite crust.

Microbialites recovered from deeper water, between 120 and $140 \mathrm{~m}$ yielded ages that are remarkably concentrated between $13,400 \pm 500$ and $13,100 \pm 1,500$ yrs BP.

\subsubsection{Biological succession}

The microbialites are characteristically involved in a biological succession and sedimentary sequence that includes corals, other encrusting organisms (mainly red algae and crustose foraminifers), borers (cyanobacteria, sponges, worms), microbial crusts, phosphatic-iron- manganese crusts, reworked shallowwater sediments and planktonic micritic limestones (Figs $3 \& 4$ ). Similar sedimentary sequences have been reported from the tops of drowned carbonate platforms in the Huon Gulf, but it is not known if microbialites are included because the origin of micritic crusts interlayered with red algae and encrusting foraminifers was not discussed (Webster et al., 2004a).

Multiple generations of borings in algal-foraminiferal crusts, microbialites and phosphatic coatings indicate that bioerosion has been a significant process throughout the drowning event. The suite of biological communities and sediments described records drowning in response to sea level rise during the Last Deglaciation, and resembles the signatures described by Schlager $(1989 ; 1998)$.

Microbialites generally form a late stage of encrustation of coral colonies, or more commonly, of associated encrusting organisms (red algae and crustose foraminifers; Figs 2 to 4). The occurrence of borings in corals and algal-foraminiferal crusts that do not affect microbialites indicates that some time elapsed prior to microbialite formation.

With the exception of the 16,000-17,000 years old examples that encrust the shallow water algalforaminiferal assemblage (Assemblage I) in the 100-120 m present depth range, microbialites generally overlie either redeposited coarse skeletal limestones or algal-foraminiferal Assemblages II and III that characterize deeper environments, at depths of $10-20 \mathrm{~m}$ and 20 to $>100 \mathrm{~m}$ respectively. 


\subsubsection{Description}

The microbialites recovered on the Tahiti and Marquesas islands slopes are characterized by a suite of characteristic fabrics. Their growth forms, great variations in thickness, lateral persistence and small-scale internal structures, allow them to be interpreted as bio-accretionary features (see Camoin et al., 1999). They form crusts on average few centimeters thick, locally up to $10 \mathrm{~cm}$, that comprise stacked generations of accretions displaying a wide range of growth forms, ranging from irregular domes and bulbs to columnar forms (Figs 2 to 4). They closely resemble micritic crusts on other deep fore-reef slopes (James and Ginsburg, 1979; Land and Moore, 1980; Brachert and Dullo, 1991, 1994).

All consist of micrite but their internal structure ranges from featureless clotted aggregates to dense forms with crude laterally impersistent planar or wavy lamination (Fig. 4). Small grains trapped in the microbial fabrics include volcanic minerals, phosphate, fragments of red algae, scarce planktonic and benthic foraminifers and spicules of alcyonarians (see Fig. 4). The occurrence of such grains on vertical faces suggests that the surfaces of the crusts were at least periodically sticky, perhaps mucilaginous. Sediments consisting of similar grains are locally interlayered between successive microbial crusts and fill microcavities between adjacent microbial accretions. However, the relative scarcity of extraneous particles in crusts suggests that sediment trapping was much less important than calcification of organic mucilage associated with living or decaying organisms, and in-place, microbially-mediated, precipitation of micrite. Rapid lithification may be deduced from the presence of borings in microbialites and local reworking of crusts as angular clasts in overlying slope sediments. The nature, origin and sedimentological roles of these microbialites will be the subject of a separate paper.

Isolated or interconnected irregular microcavities, up to $1 \mathrm{~cm}$ in size, commonly occur between microbial accretions and seemingly represent primary voids partly filled with fine-grained sediments (e.g. Fig. 2D). Encrusting foraminifers and worm tubes are commonly intercalated between crusts. The only exceptions are the 16,000-17,000 years old microbialites in the present 100-120 m depth range in which primary voids in the microbial fabrics are filled with shallow-water skeletal sediments rich in fragments of branching red algae, corals, molluscs and foraminiferal crusts.

Microbialites are typically stained by phosphate and iron oxides, indicating that the microbial development and precipitation of phosphates and iron occurred coevally. Furthermore, phosphatic and ironbearing films are commonly interlayered with microbial laminae towards the outer surfaces of the crusts and coat borings in both the microbialite and underlying red algal-foraminiferal encrustations. Brachert and Dullo (1994) noticed that similar laminar crusts recovered on deep fore-reef slopes from the Red Sea represent a combination of biogenic crusts and laminar Fe-impregnation related to hard ground formation.

\subsubsection{Mineralogy and geochemistry}

$\mathrm{XRD}$ analysis indicates that the microbialites are composed of microcrystalline high-Mg calcite containing 7 $16 \mathrm{~mol} \% \mathrm{MgCO}_{3}$, together with traces of aragonite derived from the incorporation of comminuted skeletal fragments.

Microbialites from Tahiti and the Marquesas islands display very similar isotopic compositions regardless of their age and sampling depths. They exhibit a narrow range of carbon and oxygen isotope values varying from +1.97 to $+3.69 \%$ o $\delta^{13}$ C PDB (mean $+2.89 \%$; $n=46$ ) with a standard deviation of $0.01 \%$, and -0.86 to $+1.15 \% \delta^{18}$ O PDB (mean $-0.16 \%$; $n=46$ ) with a standard deviation of $0.02 \%$. These values are typical for a non-enzymatic fractionation and are close to those expected for calcitic cements precipitated at equilibrium with normal sea water (e.g. Mg-calcite cements from Mururoa atoll give values of $+2,83$ to $+4,11$ $\% o \delta^{13} \mathrm{C}$ and $+0,44$ to $+1,90 \% \delta^{18} \mathrm{O}$; Ebren, 1996; Camoin et al., work in progress). Such values are also close to those of microbialites recovered in cores through the barrier reef off Papeete (mean $+3.37 \%$ o $\delta^{13} \mathrm{C}$ PDB and $0 \% \delta^{18} \mathrm{O}$; Camoin et al., 1999) and fall within the range of results from similar crusts in Holocene reefs on Mauritius and Mayotte (mean $+2.73 \% \delta^{13} \mathrm{C}$ and $-0.42 \% \circ \delta^{18} \mathrm{O}$; Camoin et al., 1997), Jamaica (mean $+3.0 \% \pm 1.0 \delta^{13} \mathrm{C}$ and $-0.5 \% \pm \pm 1.0 \delta^{18} \mathrm{O}$; Land and Goreau, 1970), Heron Island (mean $+3.48 \% \pm 0.03 \delta^{13} \mathrm{C}$ and $-0.02 \% \pm 0.03 \delta^{18} \mathrm{O}$, Camoin et al., 1999) and Vanuatu (Cabioch et al., this volume). It is interesting to note, however, that while $\delta^{13} \mathrm{C}$ values are remarkably similar, the $\delta^{18} \mathrm{O}$ average values of the Tahiti and Marquesas microbialites are intermediate between those of microbialites developed on deep fore-reef slopes (e.g. ledge rocks; see Brachert and Dullo, 1991; Dullo et al., 1998) $\left(\delta^{18} \mathrm{O}+0.90\right.$ to $+2.32 \%$; Camoin et al., 1999) and those in shallow-water caves (e.g. Lizard Island, GBR; $\delta^{18} \mathrm{O}-1$ to $-0.5 \%$; Reitner, 1993; Reitner et al., 1995). 


\section{Discussion}

The Last Deglaciation was characterized by a rapid sea level rise and abrupt climatic change, with coeval alteration of ecological conditions, including bathymetry, light intensity, terrigenous flux, nutrient concentrations etc.

The data acquired on the fore-reef slopes of Tahiti and the Marquesas islands document the early history of the Last Deglaciation sea level rise and therefore complete the picture of the last 13,000 years obtained from boreholes in the Papeete barrier reef (Montaggioni et al., 1997; Cabioch et al., 1999; Camoin et al., 1999).

The reef foreslopes of Tahiti and the Marquesas islands contain a primary record of reef growth, reef drowning and erosion related to the last deglacial sea level rise. The data presented provide a detailed chronology of sea level and environmental changes within that time window. The corals dredged within the $100-120 \mathrm{~m}$ present depth range in both sites yield ages ranging from 15,000 to $16,000 \mathrm{yrs} \mathrm{BP}$, indicating that they grew prior to the meltwater pulse event MWP-1A that is thought to have been characterized by a very rapid sea level rise (40 to 50 mm/yr), around 14 ka (Fairbanks, 1989; Bard et al., 1990; Hanebuth et al., 2000; Clark et al., 2002).

\subsection{Distribution of microbialites in the last deglacial reef sequence}

The reconstruction of depositional environments based on biological successions and sedimentary sequences provides some insight into the environmental changes that reefs had to face during the Last Deglaciation. Microbialites are of pivotal interest in such reconstructions because of their widespread occurrence in Late Pleistocene to Holocene reef frameworks (review in Camoin et al., 1999) where they commonly appear as major structural and volumetric components, locally forming up to $80 \%$ of the reef rock (Camoin and Montaggioni, 1994; Camoin et al., 1999).

Microbialites occur at all depths in the sites studied and yield ages ranging from $17,100 \pm 2,900$ to $4,410 \pm$ 2,250 yrs BP, suggesting that they played a prominent role during the Last Deglaciation, confirming previous conclusions based on study of the Papeete drill cores (Camoin et al., 1999). They developed in both shallow and deep water environments characterizing a variety of zones of the reef tracts (reef crests, upper reef slopes, deep fore-reef slopes), and thus reflecting contrasting scenarios of microbialite development involving both «reefal microbialites» and «slope microbialites». We examine below their environmental significance in reef sequences of the last deglacial interval.

The Table 2 summarizes the sampling depths and ages of microbialites collected from the fore-reef slopes of Tahiti and the Marquesas islands. The depth ranges of microbialite growths have been calculated by comparing their sampling depth to the sea level position related to their ages on the Tahiti (Bard et al., 1996) and Barbados curves (Fairbanks, 1989; Bard et al., 1990).

\subsection{Environmental significance of reefal microbialites}

Reefal microbialites occur in the $100-120 \mathrm{~m}$ present depth range where they typify growth in the 16,000 to $17,000 \mathrm{yrs}$ BP time window. They form surface crusts corresponding to a late stage of encrustation of the dead parts of coral colonies, or more commonly, of related encrusting organisms (red algae and foraminifers). This implies that some time elapsed prior to the formation of the microbialites and that there was generally no direct space competition between coralgal and microbial communities. The study of the Papeete cores (Camoin et al., 1999) reached the same conclusion, strengthened by dating results that demonstrate that microbialites are usually $\sim 2,000$ yrs younger than the corals that they encrust $(6,000$ and $8,500 \mathrm{yrs}$ old corals are encrusted by microbialites dated at $4240 \pm 80$ and $6610 \pm 70 \mathrm{yrs} \mathrm{BP}$ respectively, Montaggioni, pers. comm.). The growth of reefal microbialites over the shallow water encrusting algal-foraminiferal assemblage (Assemblage I), and their interlayering with shallow water skeletal sands, indicate that they grew in a shallow water environment. Their calculated development depth interval ranges from 0 to $25 \mathrm{~m}$, taking into account the uncertainty concerning their ages (Tab. 2), and this is in good agreement with the paleoenvironmental reconstruction based on the succession of sedimentary facies and biological communities.

The scenario of their development is therefore similar to that suggested for the microbialites in the Papeete drill cores that developed in cryptic niches, perhaps some distance within the reef framework. We have earlier demonstrated that in addition to the overall decrease in light and hydrodynamic energy, reflecting progressive burial of the framework by later coral growth, the key prerequisite for the widespread development of microbialites in cryptic niches may be related to other subtle fluctuations in ecological parameters, including in particular increased alkalinity and nutrient availability in interstitial waters due to 
terrestrial groundwater seepage and periodic runoff (Camoin et al., 1999). Surface fluxes (from adjacent rivers) are typified by the trapping of reworked volcanic minerals in microbial fabrics and by the interlayering of fine-grained volcaniclastic sands between microbial crusts. Since the work of Hallock and Schlager (1986), who hypothesized the negative effect of massive nutrient inputs on carbonate platform development, it has been demonstrated that increases in nutrient concentration may significantly hamper the accretion of coral reefs and favour the growth of algal turf (Hallock, 1988; Mutti and Hallock, 2003) and, ultimately, the development of microbialites (Sprachta et al., 2001; Camoin and Golubic, work in progress).

Microbialites reported in various Late Pleistocene to Holocene reef frameworks (e.g. Indian Ocean, Camoin et al., 1997, 2004; Great Barrier Reef, Webb and Jell, 1997; Vanuatu, Cabioch et al., 1998, 1999) also developed in shallow-water settings and are therefore regarded as "reefal microbialites".

\subsection{Environmental significance of slope microbialites}

Slope microbialites correspond generally to the ultimate stage of a biological succession indicating a deepening sequence. Shallow water corals and associated encrusting organisms (algal-foraminiferal crusts of Assemblage I) are replaced by deeper water assemblages of red algae and foraminifers. The latter include Assemblages II and III that typify environments at depths of $10-20 \mathrm{~m}$ and greater than $20 \mathrm{~m}$ (extending to more than $100 \mathrm{~m}$ ) respectively, implying that the associated microbialites formed at similar depths. This conclusion is supported by the calculated development depth interval of microbialites based on relative sea level that ranges generally from 50 to $100 \mathrm{~m}$, taking into account the uncertainty concerning their ages (Tab. 2). The growth of microbialites was typically followed by the development of phosphaticiron-manganese crusts. However, the frequent trapping of reworked phosphate grains indicates that phosphate formation at least was partly coeval with microbialite development. The deposition of micritic planktonic limestones capping the phosphatic-manganese crusts suggests a deep water environment (probably $>100 \mathrm{~m}$ ) below the photic zone.

In the Red Sea, slowly accreting laminar micritic crusts formed isopachous layers on the upper surfaces of ledge rocks that characterize the fore-reef slopes of atolls and barrier reefs, at depths ranging from 120 to $200 \mathrm{~m}$ (Brachert and Dullo, 1991, 1994). The timing of this microbialite accretion was estimated between 10,000 and 8,000 yrs BP, based on the ${ }^{14} \mathrm{C}$ ages of ahermatypic corals collected from the centres of the ledges and on oxygen isotope values from microbialite crusts (Brachert and Dullo, 1991). These dates and the relative sea level curve suggest that the microbialites formed at depths of $70-160 \mathrm{~m}$. Similar microbialites are present on ledge rocks that characterize the reef wall off Mayotte (Indian Ocean), between 90 and $190 \mathrm{~m}$ water depths (Dullo et al., 1998). Laminated micritic crusts have been reported between 100 and $120 \mathrm{~m}$ water depth from the fore-reef slopes off Belize and Jamaica. These form domal structures, a few millimetres to a centimetre in size that constitute significant volumes of these rocks (James and Ginsburg, 1979; Land and Moore, 1980). The ages obtained from Belize range from 7,900 to 15,000 yrs BP (James and Ginsburg, 1979) and those from Jamaica from 9,500 to 12,500 yrs BP (Land and Moore, 1980), indicating that they formed during the Last Deglaciation, principally at depths between 50 and $70 \mathrm{~m}$. These results support the view that microbialite development was widespread in a variety of environmental settings and especially in fore-reef environments in the 50-100 m depth range during the early part of the Last Deglaciation. The coeval development of microbialites in even deeper water is suggested by the occurrence of stromatolites in the axial Red Sea basin (512 to $2704 \mathrm{~m}$ below present sea level) where pelagic sedimentation rates dropped to a minimum due to high surface water salinities during the Last Glacial Maximum and for the early part of the Last Deglaciation (Brachert, 1999).

High-precision U-series age measurements obtained from both corals and microbialites collected on the Tahiti and Marquesas fore-reef slopes constrain the timing of the successive events and the depth range of microbialite development. The age differences between the corals and overlying slope microbialites range from 1,600 to $8,400 \mathrm{yrs}$ and indicate that a significant time, several thousand years, elapsed between the development of coralgal frameworks and the growth of slope microbialite crusts. The absolute ages of microbialites imply that the microbialites cannot be considered to result from the drowning event around 14000 yrs BP, (synchronous with the MWP-1A defined by Fairbanks, 1989 and Bard et al., 1990) that resulted in the demise of reef frameworks in the 90-110 m present depth range, but are substantially younger. Webster et al. (2004b) have demonstrated that deep-water coralline algae crust, formed 1,000 to 4,000 yrs ago on coral reefs off Hawaii that were drowned during the MPW-1A. Thus, although the development of these microbialites characterizes a drowning sequence related to the last deglacial sea level rise, we find no evidence that their development occurred specifically during a period of accelerated rise in sea level as Brachert and Dullo (1991; 1994) suggested for ledge rocks.

Depth and light do not seem to have been strong limiting factors. Microbialites have been reported in deeper water settings in the Red Sea (Brachert, 1999), indicating that the microbial involved communities can thrive at very low light levels. 
Burial by sediments is thought to be an important factor controlling the development of microbial fabrics in aphotic water. In the fossil record, deep water stromatolites (Playford et al., 1976; Böhm and Brachert, 1993), micrite crusts in deep shelf settings and forereef environments (Brachert and Dullo, 1991; 1994; Land and Moore, 1980 etc.) and pelagic phosphatic stromatolites (Martin-Algarra and Vera, 1994; Vera and Martin-Algarra, 1994) all formed under low rates of sedimentation reflected in stratigraphic condensation. Brachert and Dullo, $(1991,1994)$ considered extensive sediment cover as the major controlling factor on ledge development on the Red Sea foreslopes. The data from Tahiti and the Marquesas slopes confirm this interpretation. The widespread occurrence of encrusting organisms associated with hard grounds and phosphatic crusts indicates that there were low rates of sedimentation at the time of microbialite development on fore-reef slopes, probably related to rapid sea level rise. The scarcity of volcanic grains trapped in microbialites suggests that terrigenous fluxes from the islands were very limited during their growth.

The biological succession in slope environments includes corals, encrusting organisms (mainly red algae and foraminifers), borers (cyanobacteria, sponges, worms), microbial crusts, and then additional encrusters and borers (especially worms). This may reflect changes in water quality, and especially an increase in nutrients. Rates of nutrient supply are a primary controlling mechanism for benthic communities in shallow, tropical environments (Hallock and Schlager 1986; Hallock 2001; Mutti and Hallock, 2003). Bioeroding organisms such as molluscs and serpulids are typically suspension feeders and adapt to the mesotrophic conditions associated with high nutrient levels in the water column (Hallock and Schlager, 1986; Hallock, 1988). Microbialites flourish in response to short-term increases in nutrient concentrations in modern reef environments (Sprachta et al., 2001; Camoin and Golubic, work in progress).

Community changes driven by abrupt increases in nutrients can take place within a few years (e.g., Cockey et al. 1996; Sprachta et al., 2001; Mutti and Hallock, 2003) and are far more rapid than those brought about by rapid sea-level rise that reflect time scales of at least decades (Blanchon and Shaw, 1995; Dullo et al., 1998; Camoin et al., 2004). In the environmental settings considered, and in the context of a general sea level rise during the Last Deglaciation, a marine source of nutrients is likely and was probably related to upwelling of deeper waters, ensuring a continuing nutrient supply. The rapid sea-level rise of the deglaciation period probably led to continuous and increasing upwelling that provided additional trophic resources on the fore-reef slopes and increased flux of organic matter to the seafloor in the absence of sedimentation. It has been demonstrated in the Gulf of Aden (Benzoni et al., 2003) that nutrients carried by upwelling may disturb or prevent reef development. The growth of Halimeda mounds in tropical waters during the sea level rise has been attributed to widespread mesotrophic conditions related to upwelling (Davies and Marshall 1985; Hine et al. 1987; Marshall and Davies, 1988; Roberts et al. 1988), but no direct relationship has been demonstrated.

Further indication of important upwelling activity on the Tahiti and Marquesas slopes during the last deglacial sea-level rise is provided by the widespread development of phosphatic surface crusts. A similar succession of events, involving the occurrence of diagenetic features such as microbial micrite and phosphatic microspherules, that precipitated in the absence of sedimentation at the seafloor has been reported in non-tropical carbonates from Maiella (Italy), where it has been interpreted as the result of increased nutrient supply (Mutti and Bernoulli, 2003). As summarized by Mutti and Bernouilli (2003), the precipitation of phosphates occurs at or near the sediment-water interface, in the suboxic zone and generally requires an increased supply of organic matter to the sea floor, and is commonly related to the intense biological productivity of upwelling areas (Jarvis et al., 1994; Schenau et al., 2000). Microbial activity, typified by the coeval development of microbialites, may have played a significant role in the production of dissolved phosphate to interstitial solutions through the decomposition of organic matter, as described in recent sediments from the Peru continental margin by Froelich et al., (1988).

\section{Conclusions}

Reef rocks dredged on the fore-reef slopes of two Polynesian sites, Tahiti and the Marquesas islands, afford the opportunity to document the environmental changes that affected reef systems during the Last Deglaciation, a period characterized by a rapid sea-level rise and by abrupt climatic changes, with parallel changes in ecological conditions, including bathymetry, light intensity, terrigenous fluxes, nutrient concentrations, and others.

In situ microbialites are widely developed between 80 and $130 \mathrm{~m}$, where they range in ages from 17,100 \pm 2,900 to $4,410 \pm 2,250 \mathrm{yrs} \mathrm{BP}$, suggesting that they played a prominent role during the last deglacial sea level rise.

Microbialites developed in both shallow and deep water environments where they characterize various zones of the reef tracts (reef crests, upper reef slopes, deep fore-reef slopes), reflecting differing scenarios 
of microbialite development involving «reefal microbialites» in shallow-water settings and «slope microbialites» in environments deeper than 10-20 m, extending down to more than $100 \mathrm{~m}$.

Reefal microbialites correspond to a late stage of encrustation of the dead parts of coral colonies, or more commonly, of related encrusting organisms (red algae and foraminifers), thus forming surface crusts. Slope microbialites generally correspond to the ultimate stage of a biological succession indicating a deepening sequence in which shallow water corals and associated encrusting organisms (Assemblage I of algalforaminiferal crusts) are replaced by deeper water assemblages of red algae and foraminifers. Both biological successions reflect changes in water quality, and especially an increase in nutrients. In shallowwater settings, increased alkalinity and nutrient availability in interstitial waters were related to surface fluxes and terrestrial groundwater seepage while slope environments were exposed to continuous upwelling of deeper waters during sea level rise.

Following microbialite development, a suite of sedimentary features, involving the precipitation of phosphatic-iron-manganese crusts and the deposition of planktonic micritic limestones, records a deepening-upward sequence in response to sea-level rise.

Sedimentological and paleobiological observations coupled with high-precision U-series age measurements of both corals and microbialites indicate that a significant time elapsed between the development of coralgal frameworks and the growth of microbialite crusts; $2,000 \mathrm{yrs}$ or less for reefal microbialites and from 1,600 to $8,400 \mathrm{yrs}$ for slope microbialites. Microbialites cannot therefore be considered as part of the drowning event some 14000 yrs ago that resulted in the demise of reef frameworks in the 90-110 m present depth range, but are significantly younger.

The widespread development of microbialites in reef sequences coeval with the Last Deglaciation characterizes periods of environmental degradation resulting from rapid sea-level rise and abrupt climatic change. They provide a model that can be used to interpret fossil counterparts.

Because microbial fabrics were rapidly lithified, as demonstrated by a suite of sedimentological features (see also Camoin and Montaggioni, 1994; Camoin et al., 1999), it seems likely that their prominent role in Quaternary reef tracts may have significantly altered sediment transport from Quaternary reef margins to slope environments.

\section{Acknowledgements}

The authors wish to thank the Institut National des Sciences de l'Univers (CNRS) for financial support and the Institut de Recherche pour le Développement for its logistical support (i.e. R/V IRD Alis).

The authors wish to thank F. Gallois (IRD) for his participation to the unforgettable "SISMITA» cruise. Thanks are also extended to J. Iltis, Director of IRD-Tahiti, and to Captains, R. Proner and J.-F. Barazer and the crew of the R/V IRD Alis for their efficiency during the «ReMARQ» and «SISMITA» cruises. The stable isotope analyses were carried out at the Department of Paleontology of the University of Erlangen (Germany) by M. Joachimski and XRD measurements at CEREGE by D. Borschneck.

We are indebted to Colin Braithwaite and Stjepko Golubic for their reviews and valuable comments that improved the paper.

\section{References}

Adey, W.H., 1979. Crustose coralline algae as microenvironmental indicators in the Tertiary. In: Gray, J., Boucot, A.J. (Eds), Historical Biogeography, Plate Tectonics and the Changing Environment. Oregon University Press, Corvallis, pp. 459-464.

Adey, W.H., 1986. Coralline algae as indicators of sea level. In: Van de Plassche, O. (Ed.), Sea-level research, a manual for the collection and evaluation of data. Norwich, England, Geo Books, pp. 229-280.

Adey, W.H., Townsend, R.A., Boykins, W.T., 1982. The crustose coralline algae (Rhodophyta: Corallinaceae) of the Hawaian islands. Smithsonian Contrib. Mar. Sci., 15, 1-74.

Bard, E., Hamelin, B., Fairbanks, R.G., 1990. U-Th ages obtained by mass spectrometry in corals from Barbados: Sea-level during the past 130,000 years. Nature, 346, 456-458.

Bard, E., Hamelin, B., Arnold, M., Montaggioni, L.F., Cabioch, G., Faure, G., Rougerie, F., 1996. Deglacial sea level record from Tahiti corals and the timing of global meltwater discharge. Nature, 382, 241-244.

Benzoni, F., Bianchi, C.N., Morri, C., 2003. Coral communities of the northwestern Gulf of Aden (Yemen): variation in framework building related to environmental factors and biotic conditions. Coral Reefs 22, 475484. 
Blanchon, P., Shaw, J., 1995. Reef-drowning during the last deglaciation: evidence for catastrophic sea level rise and ice-sheet collapse. Geology, 23, 4-8.

Bloom, A.L., Broecker, W.S., Chappell, J.M.A., Matthews, R.K., Mesolella, K.J, 1974. Quaternary sea-level fluctuations on a tectonic coast : new $\mathrm{Th}^{230} / \mathrm{U}^{234}$ dates from the Huon Peninsula, New Guinea. Quat. Res., 4, 185-205.

Böhm, F., Brachert, T.C., 1993. Deep water stromatolites and Frutexites Maslov from the early and middle Jurassic of S-Germany and Austria. Facies, 28, 145-168.

Borowitzka, M.A., Larkum, A.W., 1986. Reef algae. Oceanus, 29, 49-54.

Bouchon, C., 1996. Recherches sur des Peuplements de Scléractiniaires Indo-pacifiques (Mer Rouge, Océan Indien, Océan Pacifique). Thèse Doct.-ès Sci. Marseille, Univ. Aix-Marseille, France.

Brachert, T.C., 1994. Palaeocecology of enigmatic tube microfossils forming «cryptalgal» fabrics (Late Quaternary, Red Sea). Paläont. Z., 68, 299-312.

Brachert, T.C., 1999. Non-skeletal carbonate production and stromatolite growth within a Pleistocene deep ocean (Last Glacial Maximum, Red Sea). Facies, 40, 211-228.

Brachert, T.C., Dullo, W.Chr., 1991. Laminar micrite crusts and associated foreslope processes, Red Sea. J. Sediment. Petrol., 61, 354-363.

Brachert, T.C., Dullo, W.Chr., 1994. Micrite crusts on Ladinian foreslopes of the Dolomites seen in the light of a modern scenario from the Red Sea. Jahrb. Geol. BA Wie, 50, 57-68.

Braga, J.C., Aguirre, J., 2004. Coralline algae indicate Pleistocene evolution from deep, open platform to outer barrier reef environments in the northern Great Barrier Reef margin. Coral Reefs, 23, 547-558.

Broecker, W.S., Thurber, D.L., Goddard, J., Ku, T.L., Matthews, R.K., Mesolella, K.J., 1968. Milankovitch hypothesis supported by precise dating of coral reefs and deep-sea sediments. Science, 159, 297-300.

Brousse, R., Chevalier, J.P., Denizot, M., Salvat, B, 1978. Etude géomorphologique des lles Marquises. Cahiers du Pacifique, 21, 9-74.

Burne, R.V., Moore, L.S., 1987. Microbialites: organosedimentary deposits of benthic microbial communities. Palaios, 2, 241-254.

Cabioch, G., Taylor, F.W., Récy, J., Edwards, R.L., Gray, S.C., Faure, G., Burr, G.S., Corrège, T., 1998. Environmental and tectonic influences on growth and internal structure of a fringing reef at Tasmaloum (South West Espiritu Santo, New Hebrides Island Arc, South West Pacific). In: Camoin, G., Davies, P.J. (Eds.), Reefs and carbonate platforms of the Pacific and Indian Ocean. Spec. Publ. Int. Ass. Sedimentol., 25, 261-277.

Cabioch, G., Camoin, G.F., Montaggioni, L.F., 1999a. Postglacial growth history of a French Polynesian barrier reef (Tahiti, central Pacific). Sedimentology, 46, 985-1000.

Cabioch, G., Montaggioni, L.F., Faure, G., Laurenti, A., 1999-b. Reef coralgal assemblages as recorders of paleobathymetry and sea level changes in the Indo-Pacific province. Quat. Sci. Rev., 18, 1681-1695.

Cabioch, G., Wallace, C.C., Ayliffe, L.K., McCulloch, M.T., Zibrowius, H., Laboute, P., Richer de Forges, B., 2000. First records of a fossil coral platform surrounding the marqueseas islands. Proceed. Ninth Interna. Coral Reef Symp., Bali, 298.

Cabioch, G., Pelletier, B., Boré, J.-M., Butscher, J., 2003. Campagne "ReMarq" à bord du N/O IRD "Alis" (2003) Cartographie par sondeur multifaisceaux et dragages des plates-formes récifales dans les îles Marquises (Polynésie Française). Rapp. mission, Sci. Terre, Géologie - Géophysique, Centre de Nouméa, 49, pp.1-21.

Camoin, G.F., Montaggioni, L.F., 1994. High energy coralgal-stromatolite frameworks from Holocene reefs (Tahiti, French Polynesia). Sedimentology, 41, 655-676.

Camoin, G.F., _Colonna, M., _Montaggioni, L.F., Casanova, J., Faure, G., Thomassin, B.A., 1997. Holocene sea level changes and $\bar{r}$ eef development in southwestern Indian Ocean. Coral Reefs, 16, $247-$ 259.

Camoin, G.F., Arnaud-Vanneau, A., Bergersen, D.D., Enos, P., Ebren, Ph., 1998. Development and demise of mid-oceanic carbonate platforms, Wodejebato Guyot (NW Pacific). In: Camoin, G., Davies, P.J. (Eds.), Reefs and carbonate platforms of the Pacific and Indian Ocean. Spec. Publ. Int. Ass. Sedimentol., 25, 3967.

Camoin, G.F., Gautret, P., Montaggioni, L.F., Cabioch, G., 1999. Nature and environmental significance of microbialites in Quaternary reefs: the Tahiti paradox. Sedim. Geol., 126, 271-304.

Camoin, G.F., Cabioch, G., Hamelin, B., Lericolais, G., 2003. Rapport de mission «SISMITA», pp. 1-20.

Camoin, G.F., Montaggioni, L.F., Braithwaite, C.J.R., 2004. Late glacial to post glacial sea levels in the Western Indian Ocean. Mar. Geol., 206, 119-146.

Chevalier, J.P., 1978. Les coraux des lles Marquises. Cah. Pacif., 21, 243-283.

Clark, P.U., Mix, A.C., 2002. Ice sheets and the sea level of the Last Glacial Maximum. Quat. Sci. Rev., 21, 1-7. 
Clouard, V., 2000. Etude géodynamique et structurale du volcanisme de la Polynésie Française de 84 Ma à l'Actuel. Thèse Doct. Univ. Polynésie Française, 262 pp.

Cockey, E.M., Hallock, P., Lidz, B.H., 1996. Decadal-scale changes in benthic foraminiferal assemblages off Key Largo, Florida. Coral Reefs, 15, 237-248.

Davies P.S., Marshall, J.F., 1985. Halimeda bioherms-low energy reefs, northern Great Barrier Reef. Proceed. 5th Int. Coral Reef Symp. 5, 1-7.

Davies, P.J., Braga, J.C, Lund M. Y., Webster, J. 2004. Holocene Deep Water Algal Buildups on Eastern Australian Shelf. Palaios, 19, 598-609.

Delesalle, B., Galzin, R., Salvat, B., 1985. French Polynesian coral reefs. Proceed. Fifth Intern. Coral Reef Congr., Papeete, 1, 1-554.

Done, T.J., 1982. Patterns in the distribution of coral communities across the central Great Barrier Reef. Coral Reefs, 1, 95-107.

Dullo, W.-Ch., Camoin, G.F., Blomeier, D., Casanova, J., Colonna, M., Eisenhauer, A., Faure, G., Thomassin, B.A., 1998. Sediments and sea level changes of the foreslopes of Mayotte, Comoro islands: direct observations from submersible. In: Camoin, G., Davies, P.J. (Eds.), Reefs and carbonate platforms of the Pacific and Indian Ocean. Spec. Publ. Int. Ass. Sedimentol., 25, 219-236.

Ebren, Ph., 1996. Impact des Variations Rapides du Niveau Marin sur le Développement des Atolls au Quaternaire: Mururoa (Polynésie Française). Thèse Doct. Univ. Provence, Marseille, 310 pp.

Edwards, R.L., Chen, J.H., Wasserburg, G.J., 1987. ${ }^{238} \mathrm{U}^{234} \mathrm{U}-{ }^{230} \mathrm{Th}-{ }^{232} \mathrm{Th}$ systematics and the precise measurement of time over the past 500,000 years. Earth Planet. Sci. Lett., 81, 175-192.

Fairbanks, R.G., 1989. A 17,000-year glacio-eustatic sea-level record: Influence of glacial melting rates on the Younger Dryas event and deep-ocean circulation. Nature, 342, 637-642.

Faure, G., 1982. Recherches sur les peuplements de scléractiniaires des récifs coralliens de l'archipel des Mascareignes (Océan Indien occidental). Thèse Doct.-ès Sci. Univ. Aix-Marseille II, Marseille, pp. 1-206.

Föllmi, K.B., 1996. The phosphorus cycle, phosphogenesis and marine phosphate-rich deposits. Earth Sci. Rev., 40, 55-124.

Froehlich, P.N., Arthur, M.A., Burnett, W.C., Deakin, M., Hensley, V., Jahnke, R., Kaul, L., Kim, K-H., Roe, K., Soutar, A., Vathakanon, C., 1988. Early diagenesis of organic matter in Peru continental margin sediments: phosphorite precipitation. Mar. Geol., 80, 309-343.

Gallup, C.D., Edwards, R.L., Johnson, R.G., 1994. The timing of high sea levels over the past 200,000 years. Science, 263, 796-800.

Grammer, G.M., Ginsburg, R.N., Swart, P.K., McNeill, D.F., Jull, A.J.T., Prezbindowski, D.R., 1993. Rapid growth rates of syndepositional marine aragonite cements in steep marginal slope deposits, Bahamas and Belize. J. Sedim. Petrol., 63, 983-989.

Guille, G., Legendre, C., Maury, R., Caroff, M., Munschy, M., Blais, S., Chauvel, C., Cotten, J., Guillou, H., 2002. Les Marquises (Polynésie Française): un archipel intreaocéanique atypique. Géologie de la France, 2, 5-35.

Hallock, P., 1988. The role of nutrient availability in bioerosion: consequences to carbonate buildups. Palaeogeogr., Palaeoclimatol. Palaeoecol., 63, 275-291.

Hallock, P., 2001. Coral reefs, carbonate sedimentation, nutrients, and global change. In: Stanley, G.D. (Ed), The history and sedimentology of ancient reef ecosystems. Kluwer Academic/Plenum Publishers, New York, 387-427.

Hallock, P., Schlager, W., 1986. Nutrient excess and the demise of coral reefs and carbonate platforms. Palaios, 1, 389-398

Hanebuth, T., Statteger, K., Grootes, P.M., 2000. Rapid flooding of the Sunda Shelf: a late glacial sea level record. Science, 288, 1033-1035.

Hine, A.C., Hallock, P., Harris, M.W., Mullins, H.T., Belknap, D.F., Jaap, W.C., 1987. Halimeda bioherms along an open seaway: Miskito Channel, Nicaraguan Rise, SW Caribbean Sea. Coral Reefs, 6, 173-178.

Iryu, Y., Nakamori, T., Matsuda, S., Abe, O., 1995. Distribution of marine organisms and its geological significance in the modern reef complex of the Ryukyu Islands. Sedim.Geol. 99, 243-258.

James, N.P., Ginsburg, R.N., 1979. The seaward margin of Belize barrier and atoll reefs. Spec. Publ. Int. Ass. Sedimentol., 3, $191 \mathrm{pp}$.

Jarvis, I., Burnett, W.C., Nathan, Y., Almbaydin, F.S.M., Attia, A.K.M., Castro, L.N., Flicoteaux, R., Hilmy, M.E., Husain, V., Quatwanah, A.A., Serjani, A., Zanin, Y.N., 1994. Phosphorite geochemistry: state of the art and environmental concerns. In: Föllmi, K.B. (Ed.), Concepts and controversies in phosphogenesis. Eclog. Geol. Helv., 87, 643-700.

Kaufman, A., 1985. The distribution of ${ }^{230} \mathrm{Th} /{ }^{234} \mathrm{U}$ ages in corals and the number of last interglacial high-sea stands. Quat. Res., 25, 55-62.

Laborel, J., 1986. Vermetid gastropods as sea-level indicators. In : Van de Plassche, O. (Ed.), Sea-level Research: a Manual for the Collection and Evaluation of Data, Geo Books, Norwich, pp 281-310. 
Land, L.S., Goreau, T.F., 1970. Submarine lithification of Jamaican reefs. J. Sediment. Petrol., 40, 457462.

Land, L.S., Moore, C.H., 1980. Lithification, micritization and syndepositional diagenesis of biolithites on the Jamaican island slope. J. Sediment. Petrol., 50, 357-370.

Le Roy, I., 1994. Evolution des volcans en système de point chaud: île de Tahiti, archipel de la Société (Polynésie Française). Thèse Doct. Univ. Paris-Sud, Orsay, 271 pp.

Lighty, R. G., Macintyre, I. G., Stuckenrath, R., 1982. Acropora palmata reef framework: A reliable indicator of sea level in the Western Atlantic for the past 10000 years. Coral Reefs, 1, 125-130.

Lund, L.J., 1994. Calcareous algae of Southern Queensland, Australia: the character of mobile and fixed substrate accretions and their environmental significance. M.Sc. Thesis, University of Sydney, Sydney, 143 pp.

Lund, M.J., Davies, P.J., Braga, J.C., 2000. Coralline algal nodules of Fraser Island, eastern Australia. Facies, 42, 25-34.

Macintyre, I.G., Rützler, K., Norris, J.N., Smith, K.P., Cairns, S.D., Bucher, K.E. and Steneck, R.S., 1991. An early Holocene reef in the western Atlantic: submersible investigations of a deep relict reef off the west coast of Barbados, W.I. Coral Reefs, 10, 167-174.

Marshall, J.F., Davies, P.J., 1988. Halimeda bioherms of the northern Great Barrier Reef. Coral Reefs, 6 , 139-148.

Marshall, J.F., Tsuji, Y., Matsuda, H., Davies, P.J., Iryu, Y., Honda, N., Satoh, Y., 1998. Quaternary and Tertiary subtropical carbonate platform development on the continental margin of southern Queensland, Australia. In: Camoin, G.F., Davies, P.J. (Eds.), Reefs and Carbonate Platforms in the Pacific and Indian Oceans. Spec. Publ. Int. Ass.Sedimentol., 25, 163-195.

Martin-Algarra, A., Vera, J.A., 1994. Mesozoic pelagic phosphate stromatolites from the Penibetic (betic Cordillera, southern Spain). In: Bertrand-Sarfati, J., Monty, C.L.V. (Eds). Phanerozoic stromatolites. Dordrecht, Kluver, 345-391.

Matsuda, S., Campbell, C., Wallensky, E., 1994. Recent coralline algal assemblages at Huon Peninsula. In: Ota, Y. (Ed.), Study on Coral Reef Terraces of the Huon Peninsula, Papua New Guinea: Establishment of Quaternary Sea Level and Tectonic history. Monbusho International Research Program Preliminary Report, IGCP Contrib. 274, 111-116.

Minnery, G.A., Rezak, R., Bright, T.J., 1985. Depth zonation and growth forms of crustose coralline algae: Flower Garden Banks, Northwestern Gulf of Mexico. In: Toomey, D.F., Niteck, M.H. (Eds.), Paleoalgology: Contemporary Research and Applications. Springer, Berlin, 376.

Montaggioni, L.F., Camoin, G.F., 1993. Stromatolites associated with coralgal communities in Holocene high-energy reefs. Geology, 21, 149-152.

Montaggioni, L.F., Cabioch, G., Camoin, G.F., Bard, E., Ribaud, A., Faure, G., Déjardin, P., Récy, J., 1997. Continuous record of reef growth over the past 14 k.y. on the mid-Pacific island of Tahiti. Geology, 25, 555558.

Moore, C.H., Graham, E.A., Land, L.S., 1976. Sediment transport and dispersal across the deep fore-reef and Island slope (-55 m. to -305 m.), Discovery Bay, Jamaica. J. Sediment. Petrol., 46, 174-187.

Mutti, M., Bernoulli, D., 2003. Origin of submarine hardgrounds and early lithification on a Miocene temperate carbonate shelf (Maiella, Italy). J. Sediment. Res., 73, 296-308.

Mutti, M., Hallock, P., 2003. Carbonate systems along nutrient and temperature gradients: some sedimentological and geochemical constraints. Int. J. Earth Sci., 92, 465-475.

Paterne, M., Ayliffe, L.K., Arnold, M., Cabioch, G., Tisnérat-Laborde, N., Hatté, C., Douville, E., Bard, E., 2004. Paired ${ }^{14} \mathrm{C}$ and ${ }^{230} \mathrm{Th} / \mathrm{U}$ dating of surface corals from the Marquesas and Vanuatu (sub-Equatorial Pecific) in the 3,000 to 15,000 cal. yr interval. Radiocarbon, 46, 551-566.

Playford, P.E., Cockbain, A.E., Druce, E.C., Wray, J.L., 1976. Devonian stromatolites from the Canning basin, Western Australia. In: Walter, M.R. (Ed), Stromatolites. Developments in Sedimentology, 20. Elsevier, Amsterdam, 543-563.

Reitner, J., 1993. Modern cryptic microbialite/metazoan facies from Lizard Island (Great Barrier Reef, Australia), formation and concepts. Facies, 29, 3-40.

Reitner, J., Gautret, P., Marin, F., Neuweiler, F., 1995. Automicrites in a modern microbialite. Formation model via organic matrices (Lizard Island, Great Barrier Reef, Australia). Bull. Inst. Océanogr. Monaco, 14, 237-263.

Richard, G., 1982. Mollusques Lagunaires et Récifaux de Polynésie française. Inventaire Faunistique, Bionomie, Bilan Quantitatif, Croissance, Production. Thèse Doct. ès Sci., Univ. Paris VI.

Richer de Forges, B., Poupin, J., Laboute, P., 1999. La campagne MUSORSTOM 9 dans l'archipel des îles Marquises (Polynésie française). Compte-rendu et liste des stations. In: Crosnier, A. (Ed.), Résultats des campagnes MUSORSTOM, 20. Mém. Mus. Nat. Hist. Nat., 180, 9-29. 
Ringeltaube, P., Harvey, A., 2000. Non-geniculate coralline algae (Corallinales, Rhodophyta) on Heron Reef, Great Barrier Reef (Australia). Bot. Mar., 43, 431-454.

Rio, M., Roux, M., Guerin, H., CALSUB team, 1991. Le substrat geologique et les processus sedimentaires sur les pentes bathyales observees lors de la campagne CALSUB. Doc. Trav. IGAL Paris, 15, 57-73.

Roberts, H.H., Aharon, P., Phipps, C.V., 1988. Morphology and sedimentology of Halimeda bioherms from the eastern Java Sea (Indonesia). Coral Reefs, 6, 161-172.

Rougerie, F., Wauthy, B., Rancher, J., 1992. Le récif barrière ennoyé des lles Marquises et l'effet d'île par endo-upwelling. C.R. Acad. Sci. Paris, II, 315, 677-682.

Rougerie, F., Cabioch, G., 1997. Rapport sur la Mission PaleoMarq du N.O. "Alis" aux lles Marquises (Polynésie Française). Rapports de mission, Sci. Terre, Géologie - Géophysique, Centre de Nouméa, 15 pp.

Salvat, B., Sibuet, M., Laubier, L., 1985. Benthic megafauna observed from the submersible «Cyana» on the fore-reef slope of Tahiti (French Polynesia) between 70 and $100 \mathrm{~m}$. Proceed. Fifth Intern. Coral Reef Congr., Papeete, 2, 338.

Schenau, S.J., Slomp, C.P., De Lange, G.J., 2000. Phosphogenesis and active phosphorite formation in sediments from the Arabian oxygen minimum zone. Mar. Geol., 169, 1-20.

Schlager, W., 1989. Drowning unconformities on carbonate platforms. In: Crevello, P.D., Wilson, J.L., Sarg, J.F., Read, J.F., (Eds), Controls on Carbonate Platform and Basin Development. Spec. Publ. Soc. Econ. Paleontol. Mineral., 44, 15-25.

Schlager, W., 1998. Exposure, drowning and sequence boundaries on carbonate platforms. In: Camoin, G., Davies, P.J. (Eds.), Reefs and carbonate platforms of the Pacific and Indian Ocean. Spec. Publ. Int. Ass. Sedimentol., 25, 3-21.

Signorini, S.R., McClain, C.R., Dandonneau, Y., 1999. Mixing and phytoplancton bloom in the wake of the Marquesas Islands. J. Geophys. Res., 26, 3121-3124.

Sournia, A., 1976. Abondance du phytoplancton et absence de récifs coralliens sur les côtes des îles Marquises. C.R.Acad. Sci. Paris, D, 282, 553-555.

Sprachta, S., Camoin, G., Golubic, S., Le Campion, Th., 2001. Microbialites in a modern lagoonal environment: nature and distribution (Tikehau atoll, French Polynesia). Palaeogeogr., Palaeoclimatol., Palaeoecol., 175, 103-124.

Stirling, C.H., Esat, T.M., Lambeck, K., McCulloch, M.T., 1998. Timing and duration of the Last Interglacial: evidence for a restricted interval of widespread coral reef growth. Earth Planet. Sci. Lett., 160, 745-762.

Vera, J.A., Martin-Algarra, A., 1994. Mesozoic stratigraphic breaks and pelagic stromatolites in the Betic Cordillera, southern Spain. In: Bertrand-Sarfati, J., Monty, C.L.V. (Eds). Phanerozoic stromatolites. Dordrecht, Kluver.

Veron, J.E.N., 1986. Corals of Australia and the Indo-Pacific. Angus \& Robertson, London, 644 pp.

Webb, G.E., 1996. Was Phanerozoic reef history controlled by the distribution of non-enzymatically secreted reef carbonates (microbial carbonate and biologically induced cement). Sedimentology, 43, 947971.

Webb, G.E., Jell, J.S., 1997. Cryptic microbialite in subtidal reef framework and intertidal solution cavities in beachrock, Heron Reef, Great Barrier Reef, Australia: preliminary observations. Facies, 36, 219-223.

Webster, J.M., Wallace, L., Silver, A, E., Potts, D., Braga, J.C., Renema, W., Riker-Coleman, K., Gallup, C., 2004a. Coralgal composition of drowned carbonate platforms in the Huon Gulf, Papua New Guinea; implications for lowstand reef development and drowning. Mar. Geol., 204, 59-89.

Webster, J. M., Clague, D. A., Coleman-Riker, K., Gallup, C., Braga, J. C., Potts, D., Moore, G. J., Winterer, E., Paull, C. K., 2004b. Drowning of the $150 \mathrm{~m}$ reef off Hawaii: A casualty of global meltwater pulse 1A?, Geology, 32, 49-252. 


\section{Tables}

Table 1 - Uranium and thorium isotopic compositions and ${ }^{230} \mathrm{Th}$ ages of dredged corals and microbialites.

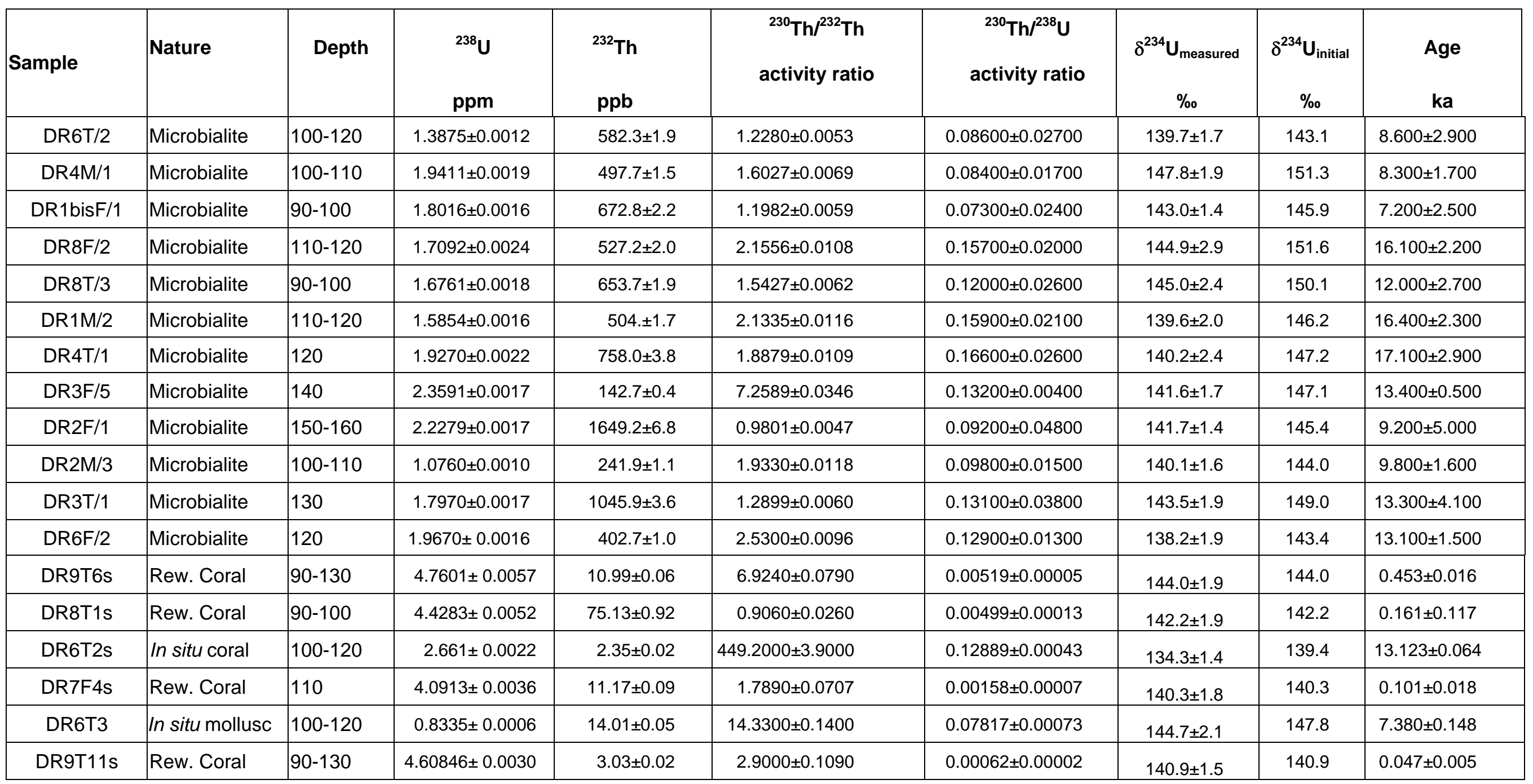




\begin{tabular}{|c|c|c|c|c|c|c|c|c|c|}
\hline DR2M1s & Rew. Coral & $100-110$ & $5.5060 \pm 0.0045$ & $9.25 \pm 0.05$ & $4.2380 \pm 0.1090$ & $0.00231 \pm 0.00006$ & $141.2 \pm 1.5$ & 141.2 & $0.190 \pm 0.012$ \\
\hline DR9T12cb & Rew. Coral & $90-130$ & $3.3235 \pm 0.0029$ & $8.71 \pm 0.06$ & $1.1910 \pm 0.1190$ & $0.00101 \pm 0.00010$ & $146.0 \pm 1.7$ & 146.0 & $0.048 \pm 0.019$ \\
\hline DR3M1s & Rew. Coral & $80-90$ & $4.5588 \pm 0.0033$ & $0.63 \pm 0.02$ & $10.0200 \pm 0.6600$ & $0.00045 \pm 0.00003$ & $140.5 \pm 1.5$ & 140.5 & $0.040 \pm 0.003$ \\
\hline DR1bisM3s & Rew. Coral & $110-140$ & $3.6669 \pm 0.0035$ & $26.65 \pm 0.17$ & $2.2540 \pm 0.0560$ & $0.00532 \pm 0.00013$ & $143.4 \pm 1.9$ & 143.4 & $0.373 \pm 0.047$ \\
\hline DR5M2su & Microbialite & $120-140$ & $2.1726 \pm 0.0016$ & $348.14 \pm 1.90$ & $2.3170 \pm 0.0390$ & $0.12046 \pm 0.00194$ & $142.9 \pm 1.5$ & 146.5 & $8.870 \pm 1.100$ \\
\hline DR2M1 & Rew. Coral & $100-110$ & $5.3718 \pm 0.0053$ & $7.51 \pm 0.04$ & $5.1490 \pm 0.0970$ & $0.00234 \pm 0.00004$ & $141.1 \pm 1.7$ & 141.1 & $0.198 \pm 0.010$ \\
\hline DR1bisM3 & Rew. Coral & $110-140$ & $3.8659 \pm 0.0035$ & $25.57 \pm 0.17$ & $2.1010 \pm 0.0660$ & $0.00451 \pm 0.00014$ & $144.2 \pm 1.5$ & 144.2 & $0.308 \pm 0.040$ \\
\hline DR1bisM2 & Rew. Coral & $110-140$ & $2.5759 \pm 0.0027$ & $44.00 \pm 0.29$ & $1.8560 \pm 0.0360$ & $0.01028 \pm 0.00018$ & $145.7 \pm 1.9$ & 145.7 & $0.665 \pm 0.110$ \\
\hline DR7T & Rew. Coral & 80- 85 & $0.4560 \pm 0.0007$ & $27.50 \pm 0,06$ & $1.7500 \pm 0.0200$ & $0.03404 \pm 0.00043$ & $145.5 \pm 3.1$ & 146.4 & $2.150 \pm 0.390$ \\
\hline DR7T & Microbialite & 80- 85 & $1.0982 \pm 0.0015$ & $382.37 \pm 1.20$ & $1.0020 \pm 0.0090$ & $0.11268 \pm 0.00093$ & $140.1 \pm 2.2$ & 141.8 & $4.410 \pm 2.250$ \\
\hline DR9T6 & Rew. Coral & $90-130$ & $4.0861 \pm 0.0033$ & $15.77 \pm 0,05$ & $2.0820 \pm 0.0450$ & $0.00260 \pm 0.00006$ & $146.2 \pm 1.5$ & 146.2 & $0.176 \pm 0.025$ \\
\hline DR9T6 & Microbialite & $90-130$ & $1.8222 \pm 0.0019$ & $386.56 \pm 0.84$ & $1.2780 \pm 0.0060$ & $0.08758 \pm 0.00040$ & $143.5 \pm 1.9$ & 145.4 & $4.525 \pm 1.370$ \\
\hline DR6T1 & In situ coral & $100-120$ & $2.4963 \pm 0.0015$ & $7.41 \pm 0.03$ & $154.0900 \pm 0.6900$ & $0.14777 \pm 0.00042$ & $140.2 \pm 1.1$ & 146.3 & $15.052 \pm 0.09$ \\
\hline
\end{tabular}


Table 2 - Sampling depths and ages of microbialites collected on Tahiti and Marquesas islands fore-reef slopes. The depth range of microbialite growth has been calculated by comparing their sampling depth to the sea level position related to their ages on the Tahiti (Bard et al., 1996) and Barbados curves (Fairbanks, 1989; Bard et al., 1990).

\begin{tabular}{|c|c|c|c|c|c|c|c|}
\hline \multirow{2}{*}{$\begin{array}{c}\text { Age } \\
\text { (ka BP) }\end{array}$} & $\begin{array}{c}\max \\
\text { age }\end{array}$ & $\begin{array}{c}\text { sea } \\
\text { level }\end{array}$ & $\begin{array}{l}\text { min devt } \\
\text { depth }\end{array}$ & $\begin{array}{l}\min \\
\text { age }\end{array}$ & $\begin{array}{c}\text { sea } \\
\text { level }\end{array}$ & $\begin{array}{c}\text { max dev } \\
\text { depth }\end{array}$ & $\begin{array}{l}\text { devt depth } \\
\text { range }\end{array}$ \\
\hline & (ka BP) & $\begin{array}{c}(\mathrm{m} \\
\text { b.p.s.l. })\end{array}$ & (m) & $\begin{array}{l}\text { (ka } \\
\mathrm{BP})\end{array}$ & $\begin{array}{c}(\mathrm{m} \\
\text { b.p.s.l. })\end{array}$ & (m) & (m) \\
\hline $\begin{array}{c}4.41 \pm \\
2.25 \\
\end{array}$ & 6.6 & 5 & 75 & 2.2 & 0 & 80 & $75-80$ \\
\hline $\begin{array}{c}12.0 \pm \\
2.7\end{array}$ & 14.7 & 97 & 0 & 9.3 & 30 & 70 & $0-70$ \\
\hline $7.2 \pm 2.5$ & 9.7 & 35 & 55 & 5.3 & 0 & 100 & $55-100$ \\
\hline $8.3 \pm 1.7$ & 10 & 40 & 60 & 6.7 & 5 & 105 & 60-105 \\
\hline $9.8 \pm 1.6$ & 11.4 & 50 & 50 & 8.2 & 20 & 90 & $50-90$ \\
\hline $\begin{array}{c}16.1 \pm \\
2.2\end{array}$ & 18.3 & 115 & 0 & 13.9 & 85 & 25 & $0-25$ \\
\hline $8.6 \pm 2.9$ & 11.5 & 50 & 50 & 5.7 & 0 & 120 & $50-120$ \\
\hline $\begin{array}{c}4.53 \pm \\
1.37\end{array}$ & 5.8 & 0 & 90 & 3.2 & 0 & 130 & $90-130$ \\
\hline $\begin{array}{c}16.4 \pm \\
2.3\end{array}$ & 18.7 & 117 & 0 & 14.1 & 95 & 25 & $0-25$ \\
\hline $\begin{array}{c}17.1 \pm \\
2.9\end{array}$ & 20 & 120 & 0 & 14.2 & 95 & 25 & $0-25$ \\
\hline $\begin{array}{c}13.1 \pm \\
1.5\end{array}$ & 14.6 & 97 & 23 & 11.6 & 55 & 65 & 23-65 \\
\hline $\begin{array}{c}13.3 \pm \\
4.1\end{array}$ & 17.4 & 110 & 20 & 9.2 & 30 & 100 & $20-100$ \\
\hline $\begin{array}{l}8.87 \pm \\
1.1\end{array}$ & 9.9 & 40 & 80 & 7.7 & 10 & 130 & $80-130$ \\
\hline $\begin{array}{c}13.4 \pm \\
0.5\end{array}$ & 13.9 & 75 & 65 & 12.9 & 67 & 73 & $65-73$ \\
\hline
\end{tabular}

\section{Figures}

Figure 1 - Location of the dredging sites around Tahiti and the Marquesas islands.

Figure 2 - Slabs of dredged reef rocks illustrating a biological succession from corals (c) over red algal crusts (al) to microbialites $(\mathrm{m})$. Microbialite crusts are often characterized by irregular dome-shaped to bulbous accretions with columnar growth (yellow arrows. A: The laminar sequence of corals, algal crusts and microbialites. Note the abundance of borings (mainly by bivalves) all three substrates. B: Microbialites, in part overlain by phosphate-iron- manganese crusts (red arrow), embedding skeletal elements (sk). C: Successional sequence modified by intermittent bioerosion. D: Massive thrombolite crust displaying interconnected irregular microcavities, up to $1 \mathrm{~cm}$ in size, that appear to represent primary voids. A Marquesas, Eiao, depth : $90 \mathrm{~m}$; B-C - Tahiti, Papenoo-Tiarei, depth : $90 \mathrm{~m}$; D- Tahiti, Papenoo-Tiarei, depth : $130 \mathrm{~m}$.

Figure 3 - Two petrographic thin sections (A and B) of columnar microbialites $(\mathrm{m})$ developed over red algal (al) and foraminifer (for) crusts. Scale bar is $1 \mathrm{~mm}$. Note that the microbialite crusts are composed of successive generations of club-shaped (?) to columnar accretions. The outer surface of the microbialites is underlined in white. Microbialite crusts are overlain by sediments rich in planktonic and benthic foraminifers 
and phosphate grains (sed) and by phosphate crusts (ph). Sample DR 1182 E, Marquesas, Nuku Hiva, 90$120 \mathrm{~m}$.

Figure 4 - Petrographic thin section of microbialites. Scale bar is $1 \mathrm{~mm}$. A: Columnar microbialites $(\mathrm{m})$ coated by phosphates (ph). Note the internal crude wavy laminations and the detrital sediments (mostly volcanic minerals) trapped within the microbial fabric ; polarized light. Sample DR3bisT, Tahiti, PapenooTiarei, depth : 130 m. B-C : Laminar to dome-shaped microbialites $(\mathrm{m})$ composed of successive generations of stacked dome-shaped accretions; note the internal crude laminations and the detrital sediments trapped within the microbial fabric. The microbialite coat corals (c) and are overlain by phosphate crusts (ph) and then by sediments rich in planktonic and benthic foraminifers and phosphate grains. Sample DR5F, Tahiti, Faaa, depth : $130 \mathrm{~m}$. 


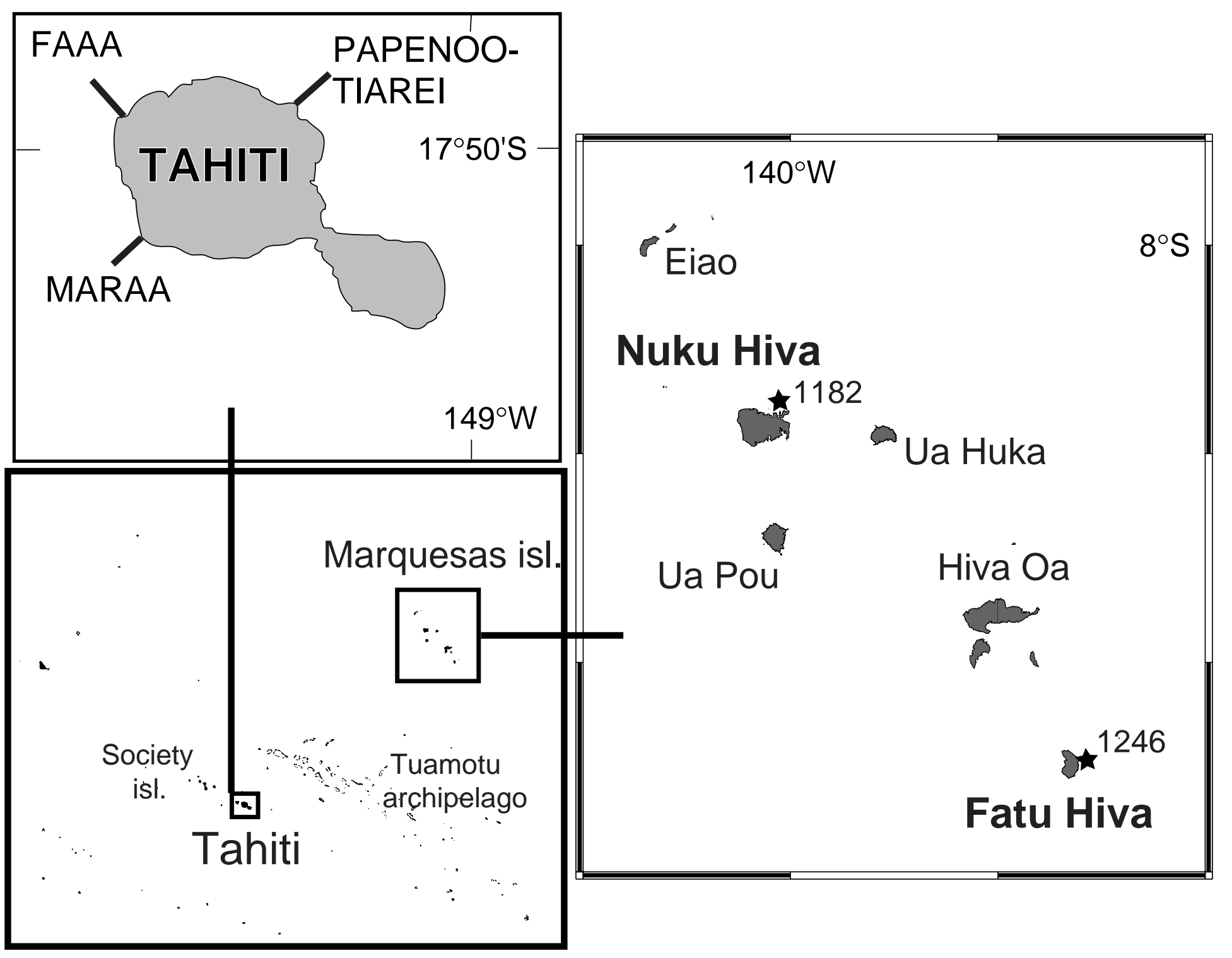



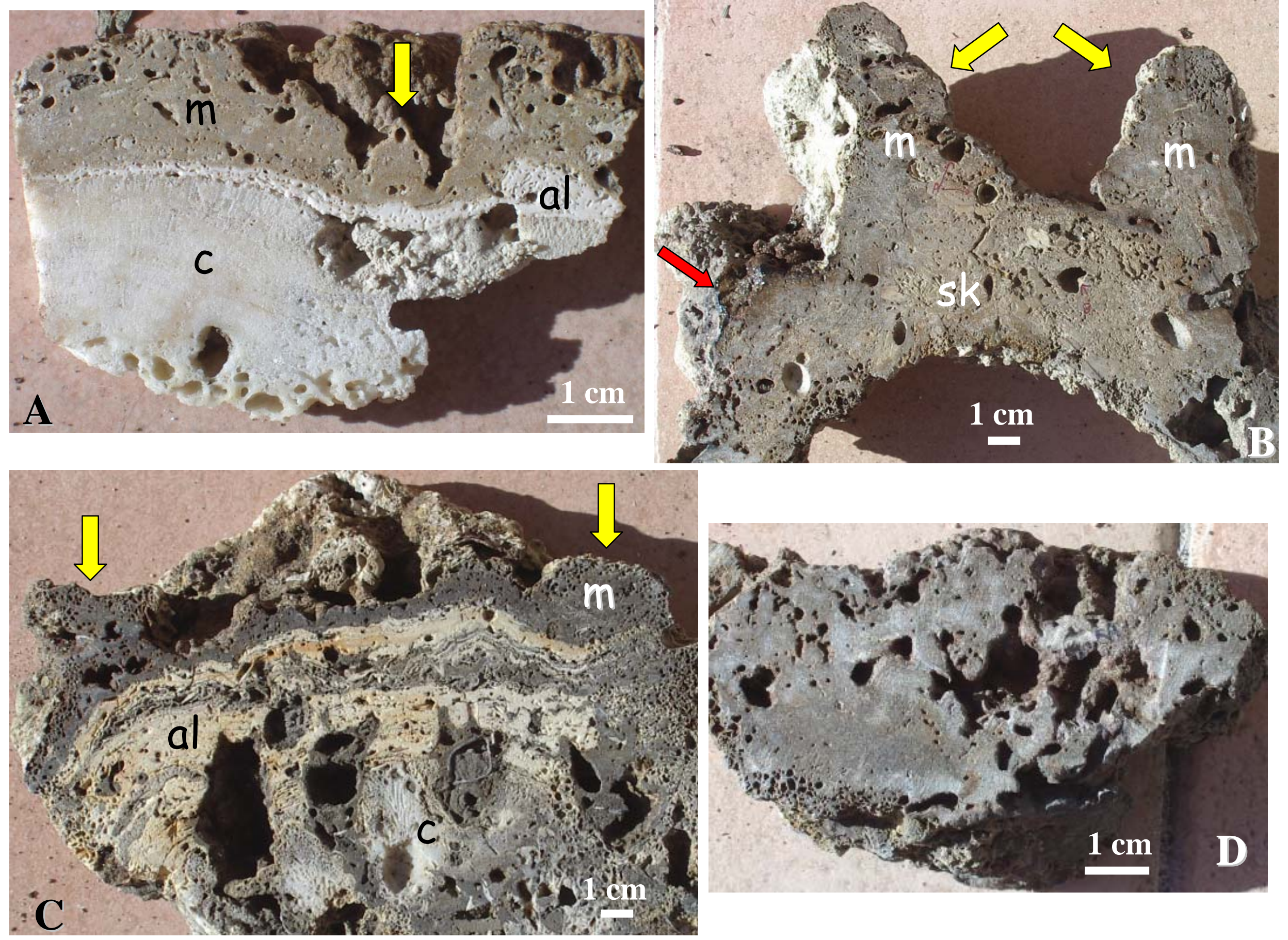

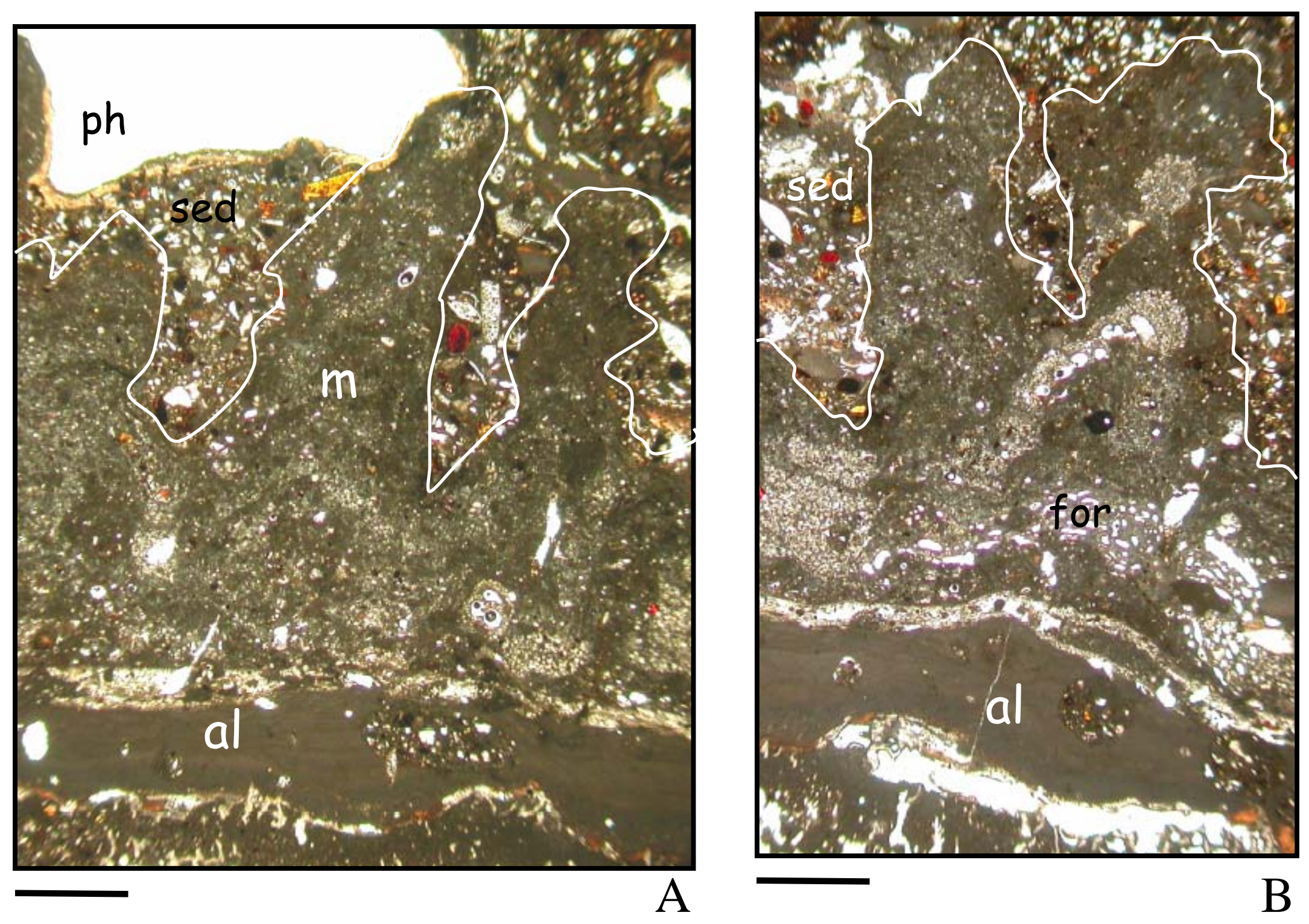

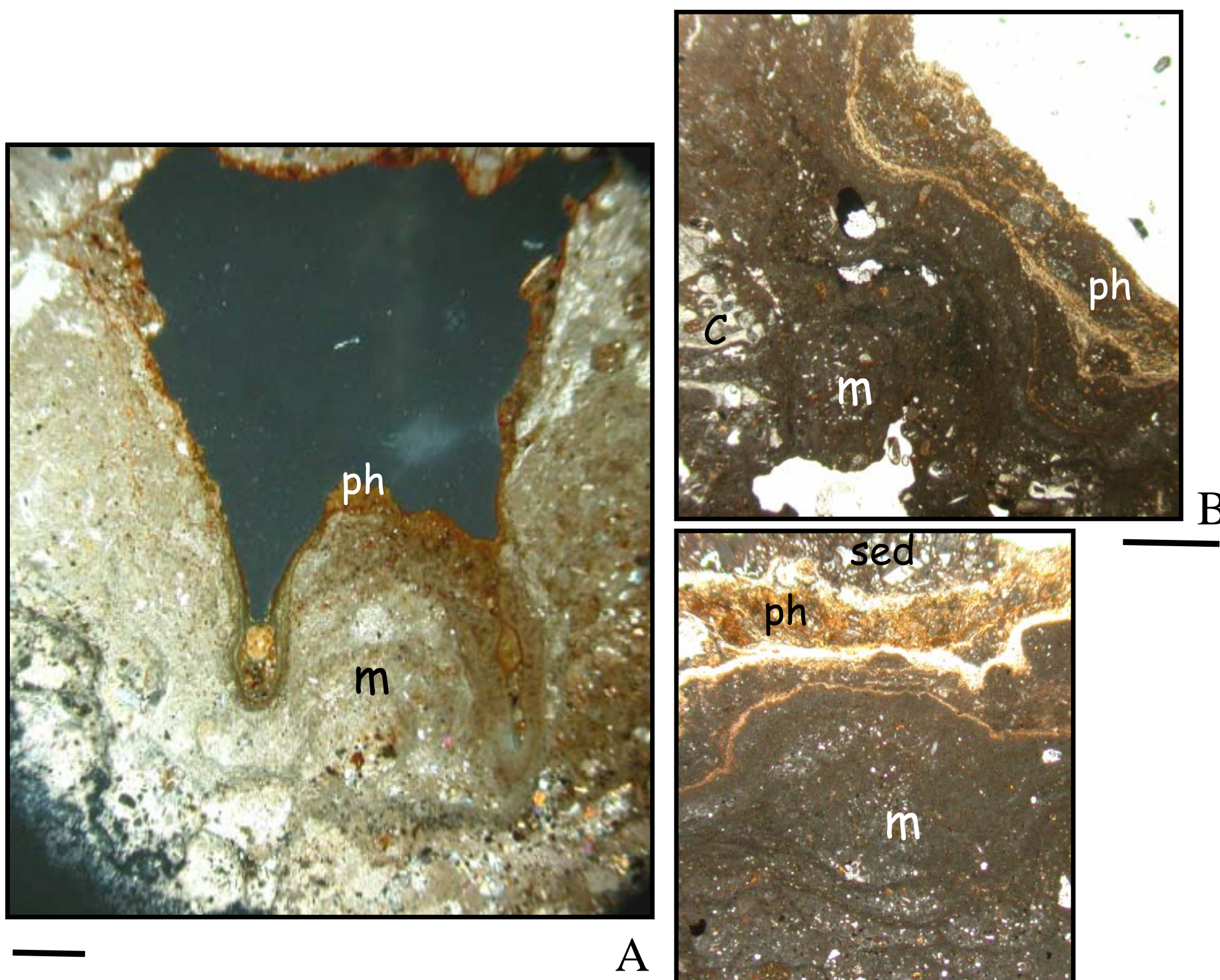

A

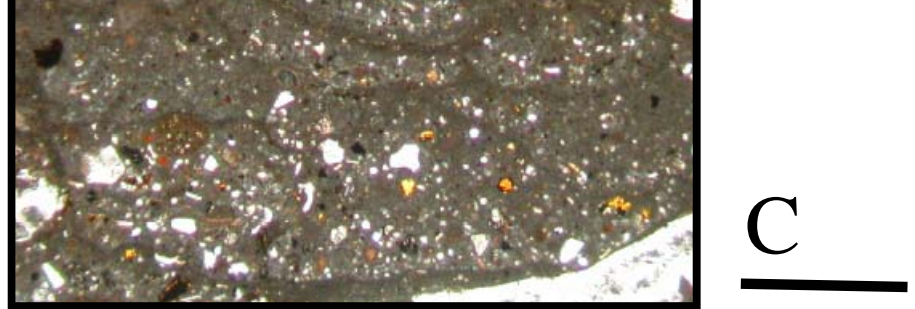

